Published in final edited form as:

Metallomics. 2019 June 19; 11(6): 1140-1153. doi:10.1039/c8mt00348c.

\title{
Manganese influx and expression of ZIP8 is essential in primary myoblasts and contributes to activation of SOD2
}

\author{
Shellaina J. V. Gordon ${ }^{\mathrm{a}}$, Daniel E. Fenker ${ }^{\mathrm{b}}$, Katherine E. Vest ${ }^{\mathrm{b},{ }^{\star}, \text { and Teresita Padilla- }}$ \\ Benavides $^{\mathrm{a},{ }^{*}}$ \\ aDepartment of Biochemistry and Molecular Pharmacology, University of Massachusetts Medical \\ School, 394 Plantation St., Worcester, MA, 01605, USA. \\ ${ }^{b}$ Department of Molecular Genetics, Biochemistry \& Microbiology, University of Cincinnati School \\ of Medicine, 231 Albert Sabin Way, Cincinnati, OH, 45267, USA.
}

\section{Abstract}

Trace elements such as copper ( $\mathrm{Cu})$, zinc $(\mathrm{Zn})$, iron $(\mathrm{Fe})$, and manganese $(\mathrm{Mn})$ function as enzyme cofactors and second messengers in cell signaling. Trace elements are emerging as key regulators of differentiation and development of mammalian tissues including blood, brain, and skeletal muscle. We previously reported an influx of $\mathrm{Cu}$ and dynamic expression of metal transporters during differentiation of skeletal muscle cells. Here, we demonstrate that during differentiation of skeletal myoblasts an increase of $\mathrm{Mn}, \mathrm{Fe}$ and $\mathrm{Zn}$ also occurs. Interestingly the $\mathrm{Mn}$ increase is concomitant with increased Mn-dependent SOD2 levels. To better understand the Mn import pathway in skeletal muscle cells, we probed the functional relevance of the closely related proteins ZIP8 and ZIP14, which are implicated in Zn, Mn, and Fe transport. Partial depletion of ZIP8 severely impaired growth of myoblasts and led to cell death under differentiation conditions, indicating that ZIP8-mediated metal transport is essential in skeletal muscle cells. Moreover, knockdown of Zip8 impaired activity of the Mn-dependent SOD2. Growth defects were partially rescued only by Mn supplementation to the medium, suggesting additional functions for ZIP8 in the skeletal muscle lineage. Restoring wild type Zip8 into the knockdown cells rescued the proliferation and differentiation phenotypes. On the other hand, knockdown of Zip14, had only a mild effect on myotube size, consistent with a role for ZIP14 in muscle hypertrophy. Simultaneous knockdown of both Zip8 and Zip14 further impaired differentiation and led cell death. This is the first report on the functional relevance of two members of the ZIP family of metal transporters in the skeletal muscle lineage, and further supports the paradigm that trace metal transporters are important modulators of mammalian tissue development.

\section{Introduction}

Transition metals such as copper $(\mathrm{Cu})$, zinc $(\mathrm{Zn})$, iron (Fe), and manganese (Mn), are essential for normal cellular function due to their roles as catalytic or structural cofactors

\footnotetext{
“Co-corresponding authors: TP-B.: terepadillabenavides@gmail.com; K.E.V.: katherine.vest@uc.edu.

Conflicts of interest

There are no conflicts to declare.

Electronic Supplementary Information (ESI) available: See DOI: 10.1039/x0xx00000x
} 
and as signalling molecules. Transition metals also function as key regulators of mammalian development ${ }^{1-8}$. For example, $\mathrm{Fe}$ is a well-characterized regulator of erythropoiesis due to the high demand for heme biosynthesis in erythroid cells (reviewed by Ganz, et al., 2012, ${ }^{9}$ ). Recent studies have implicated other transition metals such as $\mathrm{Cu}$ in the differentiation of muscle, neuronal, and blood cells $1,2,10$. Like $\mathrm{Cu}$ and $\mathrm{Fe}, \mathrm{Mn}$ acts as a catalytic or structural cofactor in enzymes involved in removal of oxygen radicals, gluconeogenesis, and protein glycosylation ${ }^{11-13}$. Excess $\mathrm{Mn}$ is toxic, and Mn accumulation leads to a neurodegenerative condition with symptoms similar to Parkinson's disease and dystonia ${ }^{14-16}$. While few cases of dietary Mn deficiency have been reported, mutations in the Mn transporter, ZIP8, have been associated with skeletal and neuromuscular symptoms ${ }^{17}$. However, few studies have shown how Mn homeostasis and other transition metals impact skeletal muscle development.

Skeletal muscle largely consists of elongated, post-mitotic myofibers and a closely associated pool of stem cells, termed satellite cells ${ }^{18-25}$. Satellite cells are critical for embryonic and early postnatal muscle development, muscle regeneration, and may be important for maintenance of basal muscle function ${ }^{26-28}$. In response to injury or muscle damage, quiescent satellite cells are activated, proliferate as myoblasts, and differentiate into myocytes to regenerate skeletal muscle myofibers ${ }^{19-22,24,25,29-38}$. During this process, multiple metabolic changes occur to meet the fluctuating energetic demands. Quiescent satellite cells typically rely on fatty acid oxidation while proliferating myoblasts primarily utilize glycolysis for energy generation ${ }^{37,39}$. During myoblast differentiation to myocytes, there is increased mitochondrial biogenesis and utilization of oxidative metabolism ${ }^{39}$. Given the importance of the mitochondrial Mn-superoxide dismutase (SOD2), Mn-influx and dynamic expression of Mn-transporting proteins are likely important factors in differentiation of skeletal muscle cells.

Several membrane metal transporters have been proposed to mobilize $\mathrm{Mn}$ in mammals ${ }^{40-45}$. Among these, two members of the family of Zrt- and Irt-like proteins (ZIP), ZIP8 (SLC39A8) and ZIP14 (SLC39A14), are considered the major Mn transporters in mammals ${ }^{41,46-48}$. ZIP transporters have been mostly characterized for their function in importing $\mathrm{Zn}$ from the extracellular milieu to the cytosol ${ }^{48-50}$. They contain eight transmembrane helices (TM), form dimers, and have nanomolar to micromolar affinity for $\mathrm{Zn}^{40,46,48,51-53}$. ZIP8 and ZIP14 have also been implicated in transport of $\mathrm{Zn}, \mathrm{Mn}, \mathrm{Fe}, \mathrm{Cu}$, and cadmium $(\mathrm{Cd})^{54}$. These two proteins are the most closely related members of the LIV-1 subfamily of ZIPs, which contains the Zn-binding motif HEXXH in transmembrane domain 5 (TM5) (reviewed by Kambe et al., 2015, and Jenkitkasemwong, et al., 2015, 48, 55 ). Both ZIP8 and ZIP14 contain a modified EEXXH motif in TM5; this single amino acid substitution may allow these proteins to transport other metals (reviewed by Jenkitkasemwong, et al., 2015, ${ }^{55}$ ). Thus, the specific metal binding residues in the TM domains of ZIP proteins may confer metal specificity.

Both ZIP8 and ZIP14 are associated with human disease. Individuals with mutations in ZIP8 experience severe neurodevelopmental defects, profound hypotonia, and skeletal abnormalities ${ }^{17,} 56$. Tissue-wide and liver-specific Zip 8 knockout in mice revealed a that ZIP8-mediated Mn uptake from the bile in hepatocytes is required for systemic Mn availability ${ }^{57}$. Individuals with mutations in ZIP14 experience parkinsonism-dystonia due to 
accumulation of toxic Mn levels ${ }^{58}$. Subsequent animal studies revealed that ZIP14 modulates systemic Mn levels by importing circulating Mn into hepatocytes ${ }^{45}$, 59-62. However, mice with liver-specific ZIP14 knockout did not accumulate Mn in the brain, indicating an important function for ZIP14 in other tissues ${ }^{60}$. Although both ZIP8 and ZIP14 are involved in liver-mediated regulation of systemic Mn, tissue-specific functions cannot be ruled out. A similar situation exists for ATP7B, which is important for copper excretion to bile in the liver, but also has important tissue-specific functions in intestinal and neuronal tissue ${ }^{63,64}$. The fact that individuals with mutations in ZIP8 and ZIP14 experience hypotonia suggests that these proteins may be important in the development or function of skeletal muscle. However, muscle phenotypes, such as regeneration after induced injury or early postnatal myogenesis have not been tested in murine ZIP8 and ZIP14 knockouts ${ }^{45,57,59-62}$.

Despite the potential role for these ZIP transporters to mobilize a variety of ions, limited information is available regarding the participation of these metals and transporters in mammalian skeletal muscle development. Importantly, our group demonstrated dynamic changes in the steady-state levels of mRNAs and proteins encoding the putative Mn transporters ZIP8 and ZIP14 during differentiation of immortalized muscle stem cell-derived C2C12 myoblasts ${ }^{65}$. Therefore, we hypothesized that a ZIP8- and/or ZIP14-mediated influx of intracellular $\mathrm{Mn}$ is necessary for myoblast differentiation.

We investigated the role of $\mathrm{Mn}$ in skeletal muscle differentiation using murine satellite cellderived primary myoblasts. We detected increased cellular $\mathrm{Mn}$ in primary myoblasts starting at $24 \mathrm{~h}$ after inducing differentiation along with increased levels and activity of the manganese-dependent SOD2. We also detected increased expression of ZIP8 and ZIP14 during myoblast differentiation, suggesting that these two transporters are important mediators of metal mobilization in differentiating skeletal muscle cells. Partial loss of ZIP8 by shRNA-mediated knockdown led to cell death when myoblasts were induced to differentiate. ZIP8 knockdown also impaired proliferation of primary myoblasts, which supports an essential role for this transporter in the skeletal muscle lineage. Knockdown of Zip14 partially impaired myotube formation but did not cause cell death indicating that ZIP14 contributes to, but is not essential for myogenesis. This study demonstrates that Mn, partially targeted to SOD2, is indispensable for the differentiation of the skeletal muscle lineage and that ZIP8 contributes to this process in primary cells. These results further support a critical role for transition metals in skeletal muscle differentiation, and this work lays the groundwork for future mechanistic studies to understand the tissue-specific transport functions of ZIP family proteins.

\section{Results}

\section{Manganese and Mn-dependent SOD2 accumulate in differentiating myoblasts}

Previous reports from our group showed that the concentrations of intracellular $\mathrm{Zn}$ and $\mathrm{Cu}$ increase during myogenesis ${ }^{2}, 65$. To better understand how other metals fluctuate during myogenesis, we utilized ICP-OES to measure total metal levels in proliferating and differentiating primary myoblasts. We detected that cellular Mn levels trended higher starting $24 \mathrm{~h}$ after inducing differentiation and were significantly increased at $72 \mathrm{~h}$ after 
differentiation (Fig. 1A). We also detected a small but not significant increase in cellular Fe after $72 \mathrm{~h}$ of differentiation (Fig. 1B). Consistent with our study of $\mathrm{Zn}$ in immortalized $\mathrm{C} 2 \mathrm{C} 12$ myoblasts $^{65}, 66$, we detected a slight increase in intracellular $\mathrm{Zn} 48 \mathrm{~h}$ after inducing differentiation in primary myoblasts (Fig. 1C). In all cases, intracellular Ca levels, which increase starting $24 \mathrm{~h}$ after inducing differentiation, were used as a positive control for differentiated muscle cells (Fig. 1D).

During differentiation, myoblasts switch from primarily glycolytic to a more oxidative metabolism ${ }^{39,67-69}$. This is associated with increased mitochondrial biogenesis and reactive oxygen species generation ${ }^{39,60-62}$. Therefore, the mitochondrial Mn-dependent SOD2 is a likely target of the increased influx of intracellular manganese during myogenic differentiation. Immunoblot analysis and in-gel activity staining revealed an increased level of SOD2 protein and activity during differentiation of primary myoblasts when compared to proliferating cells (Fig. 2). Importantly, SOD2 was distinguished from SOD1, the Cu/Zn superoxide dismutase by potassium cyanide $(\mathrm{KCN})$ inhibition ${ }^{70}$ (Supp. Fig. 1). These data suggest that SOD2 is an important target for Mn during myogenic differentiation.

\section{Expression of ZIP8 and ZIP14 increases during differentiation of primary myoblasts derived from mouse satellite cells.}

To better understand how $\mathrm{Mn}$ is transported into primary myoblasts during differentiation, we looked to the ZIP family of metal transporters. ZIP8 and ZIP14 are two homologous Zn, $\mathrm{Mn}$ and Fe transporters that share $46.6 \%$ identity and $62.0 \%$ similarity (Supp. Fig. 2). Previous investigations from our laboratory showed that in immortalized $\mathrm{C} 2 \mathrm{C} 12$ myoblasts, expression of ZIP8 but not ZIP14 was induced during myogenesis ${ }^{65}$. Here, we studied expression of ZIP8 and ZIP14 in primary myoblasts derived from mouse hind limb muscle stem cells. To determine whether the increase in ZIP8 was recapitulated in primary myoblasts, we performed immunoblots using antibodies to ZIP8 and ZIP14 in proliferating cells and cells differentiated for 24, 48, and $72 \mathrm{~h}$. As shown in Fig. 3A, levels of ZIP8 increased by approximately $50 \%$ starting $24 \mathrm{~h}$ after inducing differentiation and more than doubled after $72 \mathrm{~h}$. This is similar to the increase detected in differentiating $\mathrm{C} 2 \mathrm{C} 12$ myoblasts ${ }^{65}$. Levels of ZIP14 increased at 48 and $72 \mathrm{~h}$ after inducing differentiation (Fig. 3B). These results indicate that, unlike ZIP14 in C2C12 myoblast differentiation, levels of ZIP14 increase during later stages of primary myoblast differentiation.

\section{Zip8 and Zip14 knockdowns have differential effects on the differentiation of primary myoblasts}

Given the increased expression of ZIP8 and ZIP14 observed during primary myoblast differentiation (Fig. 3) and the roles of these proteins in Mn transport ${ }^{41,71,72}$, we hypothesized that ZIP8- and/or ZIP14-dependent Mn transport may contribute to the maturation of the skeletal muscle lineage. To determine the role of ZIP8 and ZIP14 in myoblast differentiation, we used three lentiviral contructs encoding small hairpin RNAs (shRNA) to either Zip8 or Zip14 knock down these two transporters in proliferating and differentiating myoblasts (Supp. Table 1). The virus-infected cells were selected with puromycin and the levels of ZIP8 and ZIP14 were examined by immunoblot (Fig. 3, Supp. Fig. 3). Cells containing Zip8 shRNA failed to increase expression of ZIP8 protein upon 
inducing differentiation (Fig. 3A, Supp. Fig. 3A). Cells containing Zip14 shRNA showed increased levels of ZIP14 during differentiation but to a much lesser degree and at a later time point than wild type cells (Fig. 3B, Supp. Fig. 3B).

To determine whether the partial loss of ZIP8 or ZIP14 impairs myogenesis, Zip8 and Zip14 shRNA primary myoblasts were grown to confluence and induced to differentiate by serum deprivation ${ }^{73}$. Immunocytochemical staining and immunoblot analyses for the lineage specific differentiation marker myogenin were used as indicators of myogenesis in samples taken during the proliferation stage and at 24, 48 and $72 \mathrm{~h}$ post-differentiation (Fig. 4, Supp. Fig. 4 and 5). Zip 8 knockdown cells did form elongated myocytes $24 \mathrm{~h}$ after inducing differentiation, but also detached from the plates and failed to form myotubes at later time points (Fig. 4A, Supp. Fig. 4A). The Zip8 knockdown cells had decreased myogenin positive nuclei and showed a significantly lower fusion index than wild type cells at similar time points (Fig. 4A, B, Supp. Fig. 4, 5). Cells containing Zip14 shRNA formed myotubes but also showed a lower fusion index than control cells (Fig. 4A, B, Supp. Fig. 4, 5). These results suggest that ZIP14 contributes to robust myotube formation, but ZIP8 is essential for differentiation.

The detachment detected in Zip8 differentiating knockdown cells suggests that partial loss of ZIP8 leads to cell death. A major cell death pathway is caspase 3 dependent apoptosis ${ }^{74}$. Myoblast differentiation requires the disassembly and reorganization of actin fibres and the activation of myosin light chain kinase, events that also occur during apoptosis ${ }^{75-77}$. Previous studies have shown that myogenic differentiation and apoptosis undergo similar mechanisms of cleaving and activation of caspase $3^{78-81}$. We employed immunoblot assay to detect cleaved Caspase 3 in proliferating and differentiating primary myoblasts. We found the expected low levels of cleaved caspase 3 in wild type proliferating and differentiating myoblasts (Supp. Fig. 5B). Furthermore, we observed an increase in the cleaved caspase 3 at $48 \mathrm{~h}$ after inducing myogenesis in cells transduced with the three different Zip8shRNA (Supp. Fig. 5B). No changes in the levels of cleaved caspase 3 were detected in the Zip14 treated shRNA myoblasts, which is consistent with the fact that these cells did not detach upon inducing differentiation (Supp. Fig. 5B).

\section{Zip8 knockdown cells fail to expand intracellular Mn after being induced to differentiate}

Both ZIP8 and ZIP14 have been implicated in transport of Mn, Zn and Fe (reviewed by Jenikitkasemwong, et al., 2015, ${ }^{55}$ ), which are critical for cell growth and survival ${ }^{41}$. To understand how partial loss of ZIP8 and ZIP14 affect accumulation of Mn, Fe, and Zn, we used ICP-OES to measure total metal levels in differentiating Zip8 and Zip14 knockdown cells (Fig. 5). Similar to wild type cells (Fig. 1A), myoblasts transfected with scrambled (scr) shRNA showed increased intracellular Mn starting at $24 \mathrm{~h}$ after inducing myogenesis (Fig. 6A). Cells transduced with Zip8 shRNA failed to accumulate Mn while those transduced with Zip14 shRNA accumulated the same or higher levels of Mn compared to control cells (Fig. 5A; Supp. Fig. 6). Measurement of total levels of Fe (Fig. 5B; Supp. Fig. 6), Zn (Fig. 5C; Supp. Fig. 6) revealed similar results, where wild type and Zip14 knockdown cells showed accumulation at $24 \mathrm{~h}$ after inducing differentiation. Zip8 knockdown cells accumulated $\mathrm{Mn}$ to a much lesser degree at $24 \mathrm{~h}$ after inducing 
differentiation and showed no accumulation at later time points (Figure 5A). Total Ca was measured as a positive control for myogenesis (Fig. 5D; Supp. Fig. 6). Total Ca levels increased in wild type cells and in cells transfected with scrambled shRNA or Zip14 shRNA at $24 \mathrm{~h}$ after inducing differentiation (Fig. 5C; Supp. Fig. 6). However, Zip8 knockdown cells failed to accumulate $\mathrm{Ca}$ after the differentiation stimulus (Fig. 5C; Supp. Fig. 6). These results are consistent with the severe differentiation defect observed in Zip8 knockdown cells (Fig. 4; Supp. Fig. 5).

ZIP8 has been previously shown to transport $\mathrm{Mn}^{44}$, which is a cofactor for the mitochondrial $\mathrm{SOD}^{82}$. SOD2 has a well-characterized role in maintaining redox balance and mitochondrial function in skeletal muscle, as well as in promoting proliferation and differentiation of myoblasts ${ }^{83-85}$. To determine whether differentiation defects in Zip8 knockdown myoblasts are associated with a loss of SOD2 activity, we performed immunoblot and in-gel activity assays of SOD2. As shown in Fig. 2, increased steady-state levels and activity of SOD2 were detected in differentiating wild type myoblasts. Therefore we asked whether the partial knockdown of ZIP8 or ZIP14 would impair the expression or activity of SOD2. In differentiating Zip8 knockdown myoblasts, activity of SOD2 failed to increase and SOD 2 levels increased to a much lesser degree compared to wild type cells (Fig. 6A; Supp. Fig. 7A, C). SOD2 protein levels and activity in proliferating and differentiating Zip14 knockdown myoblasts were similar to wild type and scramble control (Fig. 6B, Supp. Fig. 7B, D). Protein levels and activity of SOD2 was normalized to total protein (Supp. Fig. 8). These results could support a role for ZIP8, but not ZIP14, in providing Mn for SOD2 in differentiating myoblasts. However, impaired SOD2 activity could also be an indirect result of impaired differentiation in Zip8 knockdown cells.

\section{Knockdown of Zip8 impairs proliferation of primary myoblasts}

Considering that knockdown of Zip8 in primary myoblasts led to cell death after inducing differentiation and that $\mathrm{Mn}, \mathrm{Fe}$, and $\mathrm{Zn}$ are important for cellular growth and survival, we sought to understand how myoblasts proliferation is affected. We used cell counting to as a proxy measurement for proliferation in Zip 8 knockdown cells. While numbers of wild type myoblasts and myoblasts transduced with scrambled shRNA increased 50 fold over three days (Fig. 7, Supp. Fig. 9), cells containing Zip8 shRNA increased in number only 10 fold during the same period (Fig. 7; Supp. Fig. 9). Expression of PAX7 was normal in proliferating Zip8 knockdown cells, indicating that growth defects are not related to loss of this myoblast-specific transcription factor (Fig. 7E, F).

\section{Expression of exogenous ZIP8 rescues the proliferation and differentiation phenotypes of Zip8 knockdown}

To assess whether the proliferation and differentiation defects observed in Zip8 partially depleted myoblasts was in fact due to the loss of this transporter, we performed rescue experiments using exogenous HA-tagged murine ZIP8. Myoblasts were transduced with plasmids encoding wild type Zip8 and expression was confirmed by immunoblot for ZIP8 and for the HA-tag (Fig. 8A). Differentiation defects detected in Zip8 knockdown cells were rescued upon expression of wild type ZIP8 as shown by the expression of the myogenic marker Myogenin (Fig. 8A,B). Consistently, the levels of cleaved Caspase 3 were decreased 
relative to those detected in Zip8 knockdown cells (Fig. 8A). Interestingly, protein levels of SOD2 were higher proliferating cells expressing exogenous ZIP8 than levels of SOD2 in wild type proliferating cells (Fig. 8A). Importantly, the proliferation defect observed in Zip8 knockdown myoblasts was rescued upon expression of the exogenous wild type ZIP8 (Fig. 8C). Consistent with restored ability to differentiate, Zip8 knockdown cells expressing exogenous wild type ZIP8 showed increased levels of Mn, Fe, and Zn (Fig. 8D-F).

\section{Simultaneous knockdown of Zip8 and Zip14 exacerbates defects caused by Zip8 knockdown}

To further demonstrate the importance of ZIP8 and ZIP14 in myogenesis, we transduced cells with shRNAs targeting Zip8 and Zip14 and investigated the effect of the double knockdown on differentiation and proliferation of primary myoblasts. Simultaneous knockdown of both transporters prevented differentiation as shown by the lack of myotube formation and Myogenin expression (Fig. 9A, B). We also detected increased levels of cleaved caspase 3, indicating that double knockdown of Zip8 and Zip14 causes cell death (Fig. 9A). In fact these cells largely detached within $24 \mathrm{~h}$ after applying the differentiation stimulus, thus experiments could not be performed at later time points. SOD2 protein was undetectable by immunoblot in double knockdown cells extracted $24 \mathrm{~h}$ after being induced to differentiate (Fig. 9A). As expected, these cells showed nearly zero proliferation (Fig. 9C). Importantly, the levels of $\mathrm{Mn}, \mathrm{Fe}$ and $\mathrm{Zn}$ were dramatically decreased in double knockdown cells (Fig. 9D-F). Taken together, these data show an additive effect of knocking down both Zip8 and Zip14. This result suggests these two transporters act in different pathways and confirm their biological relevance in the skeletal muscle lineage.

\section{Manganese supplementation partially rescues the proliferation defect of Zip8 knockdown myoblasts}

To determine whether impaired metal import is responsible for the growth defect detected in Zip8 knockdown cells, we supplemented the growth medium with increasing concentrations of Mn (Fig. 10A, Supp. Fig. 10), Fe (Fig. 10B, Supp. Fig. 10), and Zn (Fig. 10C, Supp. Fig. $10)$. We found that only addition of $300 \mu \mathrm{M} \mathrm{Mn}$ to the medium partially rescued the growth defects detected in Zip8 knockdown cells while this same concentration impaired growth in wild type cells (Fig. 10A, Supp. Fig. 10). Cell counting assay revealed that control and Mntreated cells expressing Zip14 shRNA proliferated similarly to wild type and shRNA scrambled cells (Fig. 10A, Supp. Fig. 10). Interestingly, Both Zip8 and Zip14 knockdown cells were more sensitive to Fe and Zn compared to control cells (Fig. 10B, C, Supp. Fig. 10). These results indicate that partial loss of ZIP8 impacts myoblast proliferation and can be partially rescued by supplementation with exogenous Mn.

To determine whether impaired $\mathrm{Mn}$ import is responsible for differentiation defects detected in Zip8 and Zip14 knockdown cells, we supplemented differentiation medium with variable concentrations of $\mathrm{Mn}, \mathrm{Fe}$, or $\mathrm{Zn}$. None of the supplemented metals restored the differentiation defect of Zip8 knockdown cells. Fig. 10D (and Supp. Fig. 10D) show representative light microscopy images of the cells cultured at the highest non-toxic concentration of the metals to wild type cells. Higher levels of these metals were also toxic 
to the mutant cells. Interestingly, both Zip8 and Zip14 knockdown cells were sensitive to Fe and $\mathrm{Zn}$ concentrations that are not toxic to wild type cells (Fig. 10D, Supp. Fig. 10D).

Considering the minimal rescue effect of metal supplementation to the phenotypes observed in Zip8 and Zip14 knockdown cells, we used ICP-OES to assay Mn, Fe, or Zn accumulation after these metals were added to the medium. Proliferating and differentiating Zip 8 and Zip14 knockdown cells were able to accumulate Mn when it was added to the medium (Table 1). However, differentiated Zip8 and Zip14 knockdown cells accumulated 83\% and $76 \%$ less Mn than Mn-treated wild type cells, respectively (Table 1). A 64\% decrease Fe accumulation was detected in Zip8 knockdown cells, but Zip14 knockdown cells showed a nearly ten-fold increase in Fe accumulation relative to wild type cells (Table 1). Similar results were obtained after $\mathrm{Zn}$ treatment in Zip8 knockdown cells but to a much lesser degree. Variations in metal accumulations were also detected based on the shRNA construct transduced into the myoblasts (Supp. Table 2).

\section{Discussion}

Myogenesis encompasses metabolic and morphological changes that depend on the bioavailability of transition metals to enable energy production and redox homeostasis ${ }^{86,87}$. Here, we show that the intracellular concentration of Mn increases within $24 \mathrm{~h}$ of inducing differentiation in primary myoblasts. Mn influx is associated with increased expression and activity of SOD2, which is consistent with mitochondrial biogenesis in differentiating myoblasts ${ }^{39,67,68}$. We sought to understand the functional relevance of metal transporters in myogenesis and we focused on ZIP8 and ZIP14 due to their function in Mn, Fe, and Zn transport ${ }^{40,41,44,71,72}$. We detected increased expression of ZIP8 $24 \mathrm{~h}$ after inducing differentiation of primary myoblasts, which was consistent with our previous findings from $\mathrm{C} 2 \mathrm{C} 12$ cells $^{65}$. We also detected a small increase in the expression of ZIP14 after 48 to $72 \mathrm{~h}$ of differentiation. The increases in ZIP8 and ZIP14 expression suggest they are important for myoblast differentiation.

To determine the functional significance of ZIP8 expression, we knocked down Zip8 in primary myoblasts and induced them to differentiate. Zip 8 knockdown cells failed to form myotubes and did not increase expression of the differentiation marker myogenin. We observed no increase in Mn levels and a much smaller expansion of SOD2 levels and activity in Zip8 knockdown cells, which could be an indirect result of impaired differentiation or cell death. Indeed, we detected an increase in the apoptotic marker cleaved caspase-3 and a severe growth defect in Zip 8 knockdown cells. Taken together, these data indicate that ZIP8 is essential for growth, survival, and differentiation of primary myoblasts. All defects were rescued by expression of exogenous wild type ZIP8, indicating that ZIP8 essential in muscle cells. Previous studies have demonstrated that ZIP8 expression in skeletal muscle is low relative to other tissues, and that depletion of ZIP8 does not impair embryonic muscle development or cause obvious muscle degeneration ${ }^{88,} 89$. However, no previous studies have probed the functional importance of ZIP8 in muscle regeneration, post-natal satellite cells, or satellite cell-derived primary myoblasts. Given that several reports have demonstrated a connection between ZIP8 and cancer cell proliferation and survival, ZIP8 expression may be a general requirement for growth and survival in 
mammalian cells ${ }^{90,91}$. Further studies are needed to determine the link between ZIP8 and cell survival in the context of muscle and other cell types.

Zip8 knockdown caused impaired expansion of SOD2 levels and activity. A previous study of Sod $2^{+/}$myoblasts showed that partial loss of SOD2 impaired proliferation and differentiation, but not to the degree we observed ${ }^{85}$. The discrepancy between $\operatorname{Sod}^{+/-}$and Zip8 knockdown myoblasts suggests ZIP8 performs other functions in addition to import of Mn for SOD2. For example, ZIP8 expression is correlated with activation of the metalsensing transcription factor (MTF1) ${ }^{92}$, which contributes to the expression of skeletal muscle genes in myoblasts ${ }^{93}$. This model is supported by the fact that $\mathrm{Mn}$ supplementation only partially reversed the growth defect in Zip8 knockdown myoblasts. The exact substrates of ZIP8 in myoblasts remain to be elucidated but are likely $\mathrm{Mn}, \mathrm{Fe}$, and $\mathrm{Zn}$ and these may vary in different contexts. Although we detected decreased levels of $\mathrm{Mn}, \mathrm{Zn}$, and Fe in Zip8 knockdown cells, we cannot rule out the possibility that this decrease is an indirect effect of the severe growth and differentiation defect caused by partial loss of ZIP8.

To identify additional metal transporters important for myoblast differentiation, we also studied the functional relevance of the closely related transporter, ZIP14. Zip14 knockdown cells grow normally and are able to form myotubes. However, myotubes were fewer and smaller in Zip14 knockdown cells. This result suggests that ZIP14 contributes to later stages of myogenesis or myotube hypertrophy rather than myoblast differentiation. We did not detect major changes in $\mathrm{Mn}, \mathrm{Fe}$, or $\mathrm{Zn}$ accumulation in Zip14 knockdown cells. However, we observed that $\mathrm{Mn}$ accumulation was decreased and Fe accumulation was increased upon metal supplementation compared to wild type cells. Additional studies are needed to further elucidate the specific function of ZIP14 in myoblasts.

Mutations in human ZIP14 have been linked to symptoms of the early onset of Parkinsonism and dystonia ${ }^{16}$. This phenotype has been proposed to be related to Mn accumulation in the nervous system, rather than direct effects in skeletal muscle ${ }^{16}$. However, muscle phenotypes were not directly studied in patient tissues or animal models. Therefore, a muscle-specific function of ZIP14 cannot be ruled out. An RNA-Seq study comparing quiescent and activated satellite cells showed that steady-state levels of Zip14 mRNA increase two-fold in newly activated satellite cells relative to quiescent satellite cells suggesting that ZIP14 has additional functions in satellite cells beyond differentiation ${ }^{94}$. Interestingly, levels of Zip8 mRNA are also upregulated during early myogenic activation ${ }^{94}$. These two transporters may work cooperatively to mediate metal transport in activated muscle stem cells. Indeed, the subtle phenotype detected in Zip14 knockdown cells would suggests that metal transport via ZIP8 can partially compensate for the loss of ZIP14. This model is supported by the additive defects we detected in Zip8 and Zip14 double knockdown cells. However, future studies are needed to confirm the mechanistic details of ZIP8 and ZIP14 functional overlap in myoblasts.

\section{Conclusions}

This study demonstrates the role for manganese influx and SOD2 metallation in the context of skeletal muscle differentiation. We found that ZIP8 is essential in primary myoblasts 
derived from mouse satellite cells, and that ZIP14 plays a non-essential role in myotube hypertrophy. Future studies are needed to determine the mechanistic details of the interaction between ZIP8 and ZIP14 and the specific metallo-substrates of each transporter in myoblasts.

\section{Experimental procedures}

Isolation, growth and differentiation of primary myoblasts-Mice were housed in the University of Massachusetts Medical School animal care facility as specified by Institutional Animal Care and Use Committee guidelines. Primary myoblasts derived from mouse satellite cells were isolated from hind limb muscles of wild type C57B1/6 mice as previously described ${ }^{30}$. The myoblasts were grown in culture plates coated in $0.02 \%$ collagen (Advanced BioMatrix), in a 1:1 mix of DMEM and F-12 media (Gibco) supplemented with $20 \%$ fetal bovine serum, and $25 \mathrm{ng} / \mathrm{ml}$ recombinant basic FGF (Millipore). Myoblasts were induced to differentiate in DMEM containing 2\% horse serum and $1 \%$ Insulin-Transferrin-Selenium-Sodium Pyruvate (Thermo Fisher Scientific). All cells were maintained in a humidified $5 \% \mathrm{CO}_{2}$ incubator at $37^{\circ} \mathrm{C}$.

Plasmids and lentivirus production-Mission plasmids (Sigma) encoding for three different shRNA against Zip8 and Zip14 (Table S1) were isolated by using the Pure yield plasmid midiprep system (Promega) following the manufacturer's instructions. shRNA (15 $\mu \mathrm{g})$ and the packing vectors pLP1 $(15 \mu \mathrm{g}), \mathrm{pLP} 2(6 \mu \mathrm{g}), \mathrm{pSVGV}(3 \mu \mathrm{g})$ were transfected using lipofectamine 2000 (Thermo Fisher) into HEK293T cells for lentiviral production. After 24 and $48 \mathrm{~h}$ the supernatants containing viral particles were collected and filtered using a $0.22 \mu \mathrm{m}$ syringe filter (Millipore). Primary myoblasts were transduced with lentivirus in the presence of $8 \mathrm{mg} / \mathrm{ml}$ polybrene and selected with $1.5 \mu \mathrm{g} / \mathrm{ml}$ puromycin (Invitrogen). The codon-optimized cDNA of Zip8 including a C-terminal HA-tag sequence was purchased from GENEWIZ, and subsequently cloned into the pBABE retroviral vector containing a blasticidin resistance gene. The retroviral vector expressing ZIP8 was transfected into BOSC23 cells using Lipofectamine 2000 according to the manufacturer's instructions, and the retroviral particles were collected and transduced into the primary myoblasts as described above. Transduced cells were selected with media containing 4 $\mu \mathrm{g} / \mathrm{ml}$ blasticidin (Invitrogen). After selection, the cells were maintained with $1 \mu \mathrm{g} / \mathrm{ml}$ of puromycin and $2 \mu \mathrm{g} / \mathrm{ml}$ of blasticidin. Whole cell metal content analysis

Three independent biological replicates of proliferating and differentiating $(24,48$, and $72 \mathrm{~h})$ primary myoblasts were rinsed three times with PBS without $\mathrm{Ca}^{+2}$ and $\mathrm{Mg}^{+2}$ (Gibco). Cells were resuspended in $100 \mu \mathrm{l}$ PBS and lysed by sonication using a Diagenode Bioruptor UCD-200. Total protein content was quantified using Bradford assay ${ }^{95}$. The samples were resuspended in concentrated $\mathrm{HNO}_{3}$ (trace metal grade) and analyzed by inductively coupled plasma-optical emissions spectroscopy (ICP-OES) as previously described ${ }^{96}$.

Concentrations of $\mathrm{Mn}, \mathrm{Zn}, \mathrm{Fe}$, and Ca measured via ICP-OES were normalized to the initial mass of protein in each sample.

Western blot analyses-Protein samples from proliferating and differentiating primary myoblasts (control and Zip8- and Zip14-knockdown) were solubilized with RIPA buffer (10 
$\mathrm{mM}$ piperazine-N,N-bis(2-ethanesulfonic acid), $\mathrm{pH}$ 7.4, $150 \mathrm{mM} \mathrm{NaCl}, 2 \mathrm{mM}$ ethylenediamine-tetraacetic acid (EDTA), $1 \%$ Triton X-100, 0.5\% sodium deoxycholate and $10 \%$ glycerol) supplemented with Complete protease inhibitor cocktail (Roche). Protein content was quantified by Bradford ${ }^{95}$. Samples $(20 \mu \mathrm{g})$ were separated by SDS-PAGE and electrotransferred to PVDF membranes (Millipore). The proteins of interest were detected using the primary antibodies rabbit anti-ZIP8 (A10395), anti-ZIP14 (A1043), anti-SOD1 (A0274), anti-SOD2 (A1340), anti-Caspase 3 (A2156), anti-HA (AE008) from Abclonal. Mouse anti-actin (sc-8432) from Santa Cruz Biotechnologies was used as a loading control. Secondary antibodies used were horseradish peroxidase-conjugated anti-mouse and antirabbit (Thermo Fisher). Chemiluminescent detection was performed using ECL PLUS (GE Healthcare).

SOD Activity Gels-Protein samples from proliferating and differentiating primary myoblasts (control and Zip8- and Zip14-knockdown) were solubilized with RIPA buffer plus protease inhibitor cocktail and quantified by Bradford assay ${ }^{95}$. Fifty micrograms of each sample were separated using native PAGE gels. Gels were incubated for $30 \mathrm{~min}$ in $2.5 \mathrm{mM}$ nitro blue tetrazolium (Sigma), followed by a 20 -min incubation with $30 \mathrm{mM}$ potassium phosphate, $30 \mathrm{mM}$ TEMED, $30 \mathrm{mM}$ riboflavin, $\mathrm{pH} 7.8^{97}$. Superoxide dismutase activity was visualized by illuminating gels with white light for $10 \mathrm{~min}$ on a transilluminator. Areas of activity were visible as white bands against a dark background. SOD2 activity was detected as a cyanide-insensitive $26 \mathrm{KDa}$ band, while SOD1 activity was detected as a $17 \mathrm{KDa}$ band and a series of higher molecular weight oligomers (Supp. Fig. 4).

Immunocytochemistry-Proliferating and differentiating primary myoblasts (control and Zip8- and Zip14-knockdown) were fixed overnight in $10 \%$ formalin-PBS at $4{ }^{\circ} \mathrm{C}$. Samples were washed with PBS and permeabilized for $10 \mathrm{~min}$ in PBS containing $0.2 \%$ Triton X-100. Immunocytochemistry was performed using universal $\mathrm{ABC}$ kit (Vector Labs) following manufacturer's instructions. Hybridoma supernatants from the Developmental Studies Hybridoma Bank (University of Iowa) were used against myogenin (F5D, deposited by W.E. Wright), and Pax7 (deposited by A. Kawakami).

Statistical analysis-Statistical analyses were performed using Kaleidagraph (Version 4.1). Statistical significance was determined using one-way analysis of variance (ANOVA), followed by Bonferroni multiple comparison tests. Experiments where $\mathrm{P}^{<} 0.05$ were considered statistically significant.

\section{Supplementary Material}

Refer to Web version on PubMed Central for supplementary material.

\section{Acknowledgements}

This research was supported by the Faculty Diversity Scholars Award from the University of Massachusetts Medical School, to T.P.-B. S.J.V.G. was supported by the University of Massachusetts Medical School funding for the Summer Undergraduate Research Experience program. The authors thank Dr. Paul Cobine (Auburn University) for assistance with ICP-OES experiments; Dr. Pablo Reyes-Gutierrez and Ms. Daniella Cangussu for their technical assistance. 


\section{References}

1. Hatori Y, Yan Y, Schmidt K, Furukawa E, Hasan NM, Yang N, Liu CN, Sockanathan S and Lutsenko S, Neuronal differentiation is associated with a redox-regulated increase of copper flow to the secretory pathway, Nature communications, 2016, 7, 10640.

2. Vest KE, Paskavitz AL, Lee JB and Padilla-Benavides T, Dynamic changes in copper homeostasis and post-transcriptional regulation of Atp7a during myogenic differentiation, Metallomics, 2018, 10, 309-322. [PubMed: 29333545]

3. Strausak D, Mercer JF, Dieter HH, Stremmel W and Multhaup G, Copper in disorders with neurological symptoms: Alzheimer's, Menkes, and Wilson diseases, Brain research bulletin, 2001, 55, 175-185. [PubMed: 11470313]

4. Barnes N, Tsivkovskii R, Tsivkovskaia N and Lutsenko S, The copper-transporting ATPases, menkes and wilson disease proteins, have distinct roles in adult and developing cerebellum, J Biol Chem, 2005, 280, 9640-9645. [PubMed: 15634671]

5. Lasry I, Seo YA, Ityel H, Shalva N, Pode-Shakked B, Glaser F, Berman B, Berezovsky I, Goncearenco A, Klar A, Levy J, Anikster Y, Kelleher SL and Assaraf YG, A dominant negative heterozygous G87R mutation in the zinc transporter, ZnT-2 (SLC30A2), results in transient neonatal zinc deficiency, J Biol Chem, 2012, 287, 29348-29361. [PubMed: 22733820]

6. Bauerly KA, Kelleher SL and Lonnerdal B, Effects of copper supplementation on copper absorption, tissue distribution, and copper transporter expression in an infant rat model, American journal of physiology. Gastrointestinal and liver physiology, 2005, 288, G1007-1014. [PubMed: 15591161]

7. Bafaro E, Liu Y, Xu Y and Dempski RE, The emerging role of zinc transporters in cellular homeostasis and cancer, Signal transduction and targeted therapy, 2017, 2.

8. Dufner-Beattie J, Weaver BP, Geiser J, Bilgen M, Larson M, Xu W and Andrews GK, The mouse acrodermatitis enteropathica gene Slc39a4 (Zip4) is essential for early development and heterozygosity causes hypersensitivity to zinc deficiency, Human molecular genetics, 2007, 16, 1391-1399. [PubMed: 17483098]

9. Ganz T and Nemeth E, Iron metabolism: interactions with normal and disordered erythropoiesis, Cold Spring Harbor perspectives in medicine, 2012, 2, a011668.

10. Huang X, Pierce LJ, Cobine PA, Winge DR and Spangrude GJ, Copper modulates the differentiation of mouse hematopoietic progenitor cells in culture, Cell transplantation, 2009, 18, 887-897. [PubMed: 19520051]

11. Jitrapakdee S, St Maurice M, Rayment I, Cleland WW, Wallace JC and Attwood PV, Structure, mechanism and regulation of pyruvate carboxylase, Biochem J, 2008, 413, 369-387. [PubMed: 18613815]

12. Kanyo ZF, Scolnick LR, Ash DE and Christianson DW, Structure of a unique binuclear manganese cluster in arginase, Nature, 1996, 383, 554-557. [PubMed: 8849731]

13. Paul A, Belton A, Nag S, Martin I, Grotewiel MS and Duttaroy A, Reduced mitochondrial SOD displays mortality characteristics reminiscent of natural aging, Mechanisms of ageing and development, 2007, 128, 706-716. [PubMed: 18078670]

14. Martinez-Finley EJ, Gavin CE, Aschner M and Gunter TE, Manganese Neurotoxicity and the Role of Reactive Oxygen Species, Free radical biology \& medicine, 2013, 62, 65-75. [PubMed: 23395780]

15. Guilarte TR, Manganese neurotoxicity: new perspectives from behavioral, neuroimaging, and neuropathological studies in humans and non-human primates, Frontiers in aging neuroscience, 2013, 5, 23. [PubMed: 23805100]

16. Horning KJ, Caito SW, Tipps KG, Bowman AB and Aschner M, Manganese Is Essential for Neuronal Health, Annual review of nutrition, 2015, 35, 71-108.

17. Park JH, Hogrebe M, Gruneberg M, DuChesne I, von der Heiden AL, Reunert J, Schlingmann KP, Boycott KM, Beaulieu CL, Mhanni AA, Innes AM, Hortnagel K, Biskup S, Gleixner EM, Kurlemann G, Fiedler B, Omran H, Rutsch F, Wada Y, Tsiakas K, Santer R, Nebert DW, Rust S and Marquardt T, SLC39A8 Deficiency: A Disorder of Manganese Transport and Glycosylation, American journal of human genetics, 2015, 97, 894-903. [PubMed: 26637979] 
18. Sambasivan R and Tajbakhsh S, Adult skeletal muscle stem cells, Results and problems in cell differentiation, 2015, 56, 191-213. [PubMed: 25344672]

19. Motohashi N and Asakura A, Muscle satellite cell heterogeneity and self-renewal, Frontiers in cell and developmental biology, 2014, 2, 1. [PubMed: 25364710]

20. Zammit PS, Golding JP, Nagata Y, Hudon V, Partridge TA and Beauchamp JR, Muscle satellite cells adopt divergent fates: a mechanism for self-renewal?, The Journal of cell biology, 2004, 166, 347-357. [PubMed: 15277541]

21. Randolph ME and Pavlath GK, A muscle stem cell for every muscle: variability of satellite cell biology among different muscle groups, Frontiers in aging neuroscience, 2015, 7, 190. [PubMed: 26500547]

22. Boonen KJ and Post MJ, The muscle stem cell niche: regulation of satellite cells during regeneration, Tissue engineering. Part B, Reviews, 2008, 14, 419-431. [PubMed: 18817477]

23. Mauro A, Satellite cell of skeletal muscle fibers, The Journal of biophysical and biochemical cytology, 1961, 9, 493-495. [PubMed: 13768451]

24. Yin H, Price F and Rudnicki MA, Satellite cells and the muscle stem cell niche, Physiol Rev, 2013, 93, 23-67. [PubMed: 23303905]

25. Chang NC and Rudnicki MA, Satellite cells: the architects of skeletal muscle, Current topics in developmental biology, 2014, 107, 161-181. [PubMed: 24439806]

26. Dumont NA, Wang YX and Rudnicki MA, Intrinsic and extrinsic mechanisms regulating satellite cell function, Development, 2015, 142, 1572-1581. [PubMed: 25922523]

27. Baghdadi MB and Tajbakhsh S, Regulation and phylogeny of skeletal muscle regeneration, Developmental biology, 2018, 433, 200-209. [PubMed: 28811217]

28. Liu W, Klose A, Forman S, Paris ND, Wei-LaPierre L, Cortes-Lopez M, Tan A, Flaherty M, Miura P, Dirksen RT and Chakkalakal JV, Loss of adult skeletal muscle stem cells drives age-related neuromuscular junction degeneration, eLife, 2017, 6 .

29. Grounds MD, Towards understanding skeletal muscle regeneration, Pathology, research and practice, 1991, 187, 1-22.

30. Bischoff R and Heintz C, Enhancement of skeletal muscle regeneration, Developmental dynamics : an official publication of the American Association of Anatomists, 1994, 201, 41-54. [PubMed: 7803846]

31. Chambers RL and McDermott JC, Molecular basis of skeletal muscle regeneration, Canadian journal of applied physiology = Revue canadienne de physiologie appliquee, 1996, 21, 155-184. [PubMed: 8792022]

32. Cooper RN, Tajbakhsh S, Mouly V, Cossu G, Buckingham M and Butler-Browne GS, In vivo satellite cell activation via Myf5 and MyoD in regenerating mouse skeletal muscle, Journal of cell science, 1999, 112 ( Pt 17), 2895-2901. [PubMed: 10444384]

33. Seale P, Sabourin LA, Girgis-Gabardo A, Mansouri A, Gruss P and Rudnicki MA, Pax7 is required for the specification of myogenic satellite cells, Cell, 2000, 102, 777-786. [PubMed: 11030621]

34. Perry RL and Rudnick MA, Molecular mechanisms regulating myogenic determination and differentiation, Frontiers in bioscience : a journal and virtual library, 2000, 5, D750-767. [PubMed: 10966875]

35. Collins CA, Olsen I, Zammit PS, Heslop L, Petrie A, Partridge TA and Morgan JE, Stem cell function, self-renewal, and behavioral heterogeneity of cells from the adult muscle satellite cell niche, Cell, 2005, 122, 289-301. [PubMed: 16051152]

36. Pallafacchina G, Francois S, Regnault B, Czarny B, Dive V, Cumano A, Montarras D and Buckingham M, An adult tissue-specific stem cell in its niche: a gene profiling analysis of in vivo quiescent and activated muscle satellite cells, Stem cell research, 2010, 4, 77-91. [PubMed: 19962952]

37. Montarras D, L'Honore A and Buckingham M, Lying low but ready for action: the quiescent muscle satellite cell, The FEBS journal, 2013, 280, 4036-4050. [PubMed: 23735050]

38. Pawlikowski B, Pulliam C, Betta ND, Kardon G and Olwin BB, Pervasive satellite cell contribution to uninjured adult muscle fibers, Skeletal muscle, 2015, 5, 42. [PubMed: 26668715] 
39. Remels AH, Langen RC, Schrauwen P, Schaart G, Schols AM and Gosker HR, Regulation of mitochondrial biogenesis during myogenesis, Molecular and cellular endocrinology, 2010, 315, 113-120. [PubMed: 19804813]

40. Pinilla-Tenas JJ, Sparkman BK, Shawki A, Illing AC, Mitchell CJ, Zhao N, Liuzzi JP, Cousins RJ, Knutson MD and Mackenzie B, Zip14 is a complex broad-scope metal-ion transporter whose functional properties support roles in the cellular uptake of zinc and nontransferrin-bound iron, American journal of physiology. Cell physiology, 2011, 301, C862-871. [PubMed: 21653899]

41. Jenkitkasemwong S, Wang CY, Mackenzie B and Knutson MD, Physiologic implications of metalion transport by ZIP14 and ZIP8, Biometals, 2012, 25, 643-655. [PubMed: 22318508]

42. Tuschl K, Clayton PT, Gospe SM Jr., Gulab S, Ibrahim S, Singhi P, Aulakh R, Ribeiro RT, Barsottini OG, Zaki MS, Del Rosario ML, Dyack S, Price V, Rideout A, Gordon K, Wevers RA, Chong WK and Mills PB, Syndrome of hepatic cirrhosis, dystonia, polycythemia, and hypermanganesemia caused by mutations in SLC30A10, a manganese transporter in man, American journal of human genetics, 2012, 90, 457-466. [PubMed: 22341972]

43. Quadri M, Federico A, Zhao T, Breedveld GJ, Battisti C, Delnooz C, Severijnen LA, Di Toro Mammarella L, Mignarri A, Monti L, Sanna A, Lu P, Punzo F, Cossu G, Willemsen R, Rasi F, Oostra BA, van de Warrenburg BP and Bonifati V, Mutations in SLC30A10 cause parkinsonism and dystonia with hypermanganesemia, polycythemia, and chronic liver disease, American journal of human genetics, 2012, 90, 467-477. [PubMed: 22341971]

44. He L, Girijashanker K, Dalton TP, Reed J, Li H, Soleimani M and Nebert DW, ZIP8, member of the solute-carrier-39 (SLC39) metal-transporter family: characterization of transporter properties, Molecular pharmacology, 2006, 70, 171-180. [PubMed: 16638970]

45. Jenkitkasemwong S, Akinyode A, Paulus E, Weiskirchen R, Hojyo S, Fukada T, Giraldo G, Schrier J, Garcia A, Janus C, Giasson B and Knutson MD, SLC39A14 deficiency alters manganese homeostasis and excretion resulting in brain manganese accumulation and motor deficits in mice, Proc Natl Acad Sci U S A, 2018, 115, E1769-E1778. [PubMed: 29437953]

46. Dempski RE, The cation selectivity of the ZIP transporters, Curr Top Membr, 2012, 69, 221-245. [PubMed: 23046653]

47. Kambe T, Hashimoto A and Fujimoto S, Current understanding of ZIP and ZnT zinc transporters in human health and diseases, Cell Mol Life Sci, 2014, 71, 3281-3295. [PubMed: 24710731]

48. Kambe T, Tsuji T, Hashimoto A and Itsumura N, The Physiological, Biochemical, and Molecular Roles of Zinc Transporters in Zinc Homeostasis and Metabolism, Physiol Rev, 2015, 95, 749-784. [PubMed: 26084690]

49. Jeong J and Eide DJ, The SLC39 family of zinc transporters, Molecular aspects of medicine, 2013, 34, 612-619. [PubMed: 23506894]

50. Lichten LA and Cousins RJ, Mammalian zinc transporters: nutritional and physiologic regulation, Annual review of nutrition, 2009, 29, 153-176.

51. Antala S and Dempski RE, The human ZIP4 transporter has two distinct binding affinities and mediates transport of multiple transition metals, Biochemistry, 2012, 51, 963-973. [PubMed: 22242765]

52. Dufner-Beattie J, Langmade SJ, Wang F, Eide D and Andrews GK, Structure, function, and regulation of a subfamily of mouse zinc transporter genes, J Biol Chem, 2003, 278, 50142-50150. [PubMed: 14525987]

53. Gaither LA and Eide DJ, Functional expression of the human hZIP2 zinc transporter, J Biol Chem, 2000, 275, 5560-5564. [PubMed: 10681536]

54. Liuzzi JP, Aydemir F, Nam H, Knutson MD and Cousins RJ, Zip14 (Slc39a14) mediates nontransferrin-bound iron uptake into cells, Proc Natl Acad Sci U S A, 2006, 103, 13612-13617. [PubMed: 16950869]

55. Jenkitkasemwong S, Wang CY, Coffey R, Zhang W, Chan A, Biel T, Kim JS, Hojyo S, Fukada T and Knutson MD, SLC39A14 Is Required for the Development of Hepatocellular Iron Overload in Murine Models of Hereditary Hemochromatosis, Cell metabolism, 2015, 22, 138-150. [PubMed: 26028554]

56. Boycott KM, Beaulieu CL, Kernohan KD, Gebril OH, Mhanni A, Chudley AE, Redl D, Qin W, Hampson S, Kury S, Tetreault M, Puffenberger EG, Scott JN, Bezieau S, Reis A, Uebe S, 
Schumacher J, Hegele RA, McLeod DR, Galvez-Peralta M, Majewski J, Ramaekers VT, Nebert DW, Innes AM, Parboosingh JS and Abou Jamra R, Autosomal-Recessive Intellectual Disability with Cerebellar Atrophy Syndrome Caused by Mutation of the Manganese and Zinc Transporter Gene SLC39A8, American journal of human genetics, 2015, 97, 886-893. [PubMed: 26637978]

57. Lin W, Vann DR, Doulias PT, Wang T, Landesberg G, Li X, Ricciotti E, Scalia R, He M, Hand NJ and Rader DJ, Hepatic metal ion transporter ZIP8 regulates manganese homeostasis and manganese-dependent enzyme activity, The Journal of clinical investigation, 2017, 127, 24072417. [PubMed: 28481222]

58. Tuschl K, Meyer E, Valdivia LE, Zhao N, Dadswell C, Abdul-Sada A, Hung CY, Simpson MA, Chong WK, Jacques TS, Woltjer RL, Eaton S, Gregory A, Sanford L, Kara E, Houlden H, Cuno SM, Prokisch H, Valletta L, Tiranti V, Younis R, Maher ER, Spencer J, Straatman-Iwanowska A, Gissen P, Selim LA, Pintos-Morell G, Coroleu-Lletget W, Mohammad SS, Yoganathan S, Dale RC, Thomas M, Rihel J, Bodamer OA, Enns CA, Hayflick SJ, Clayton PT, Mills PB, Kurian MA and Wilson SW, Mutations in SLC39A14 disrupt manganese homeostasis and cause childhoodonset parkinsonism-dystonia, Nature communications, 2016, 7, 11601.

59. Liu C, Hutchens S, Jursa T, Shawlot W, Polishchuk EV, Polishchuk RS, Dray BK, Gore AC, Aschner M, Smith DR and Mukhopadhyay S, Hypothyroidism induced by loss of the manganese efflux transporter SLC30A10 may be explained by reduced thyroxine production, J Biol Chem, 2017, 292, 16605-16615. [PubMed: 28860195]

60. Xin Y, Gao H, Wang J, Qiang Y, Imam MU, Li Y, Zhang R, Zhang H, Yu Y, Wang H, Luo H, Shi C, Xu Y, Hojyo S, Fukada T, Min J and Wang F, Manganese transporter Slc39a14 deficiency revealed its key role in maintaining manganese homeostasis in mice, Cell discovery, 2017, 3, 17025. [PubMed: 28751976]

61. Aydemir TB and Cousins RJ, The Multiple Faces of the Metal Transporter ZIP14 (SLC39A14), The Journal of nutrition, 2018, 148, 174-184. [PubMed: 29490098]

62. Aydemir TB, Kim MH, Kim J, Colon-Perez LM, Banan G, Mareci TH, Febo M and Cousins RJ, Metal Transporter Zip14 (Slc39a14) Deletion in Mice Increases Manganese Deposition and Produces Neurotoxic Signatures and Diminished Motor Activity, The Journal of neuroscience : the official journal of the Society for Neuroscience, 2017, 37, 5996-6006. [PubMed: 28536273]

63. Pierson H, Muchenditsi A, Kim BE, Ralle M, Zachos N, Huster D and Lutsenko S, The Function of ATPase Copper Transporter ATP7B in Intestine, Gastroenterology, 2017, DOI: 10.1053/j.gastro. 2017.09.019.

64. Schmidt K, Ralle M, Schaffer T, Jayakanthan S, Bari B, Muchenditsi A and Lutsenko S, ATP7A and ATP7B copper transporters have distinct functions in the regulation of neuronal dopaminebeta-hydroxylase, J Biol Chem, 2018, 293, 20085-20098. [PubMed: 30341172]

65. Paskavitz AL, Quintana J, Cangussu D, Tavera-Montanez C, Xiao Y, Ortiz-Miranda S, Navea JG and Padilla-Benavides T, Differential expression of zinc transporters accompanies the differentiation of C2C12 myoblasts, J Trace Elem Med Biol, 2018, 49, 27-34. [PubMed: 29895369]

66. Gordon SJ, Xiao Y, Paskavitz AL, Navarro-Tito N, Navea JG, and Padilla-Benavides T, Atomic Absorbance Spectroscopy to Measure Intracellular Zinc Pools in Mammalian Cells. , Journal Visualized Experiments 2019, (Pending Publication), e59519, In-press.

67. Moyes CD, Mathieu-Costello OA, Tsuchiya N, Filburn C and Hansford RG, Mitochondrial biogenesis during cellular differentiation, The American journal of physiology, 1997, 272, C13451351. [PubMed: 9142861]

68. Moyes CD, Battersby BJ and Leary SC, Regulation of muscle mitochondrial design, The Journal of experimental biology, 1998, 201, 299-307.

69. Moyes CD, Controlling muscle mitochondrial content, The Journal of experimental biology, 2003, 206, 4385-4391. [PubMed: 14610025]

70. Rigo A, Viglino P and Rotilio G, Kinetic study of O-2 DISMUTATION BY BOVINE SUPEROXIDE DISMUTASE. Evidence for saturation of the catalytic sites by O-2, Biochemical and biophysical research communications, 1975, 63, 1013-1018. [PubMed: 236750]

71. Girijashanker K, He L, Soleimani M, Reed JM, Li H, Liu Z, Wang B, Dalton TP and Nebert DW, Slc39a14 gene encodes ZIP14, a metal/bicarbonate symporter: similarities to the ZIP8 transporter, Molecular pharmacology, 2008, 73, 1413-1423. [PubMed: 18270315] 
72. Fujishiro H, Yano Y, Takada Y, Tanihara M and Himeno S, Roles of ZIP8, ZIP14, and DMT1 in transport of cadmium and manganese in mouse kidney proximal tubule cells, Metallomics, 2012, 4, 700-708. [PubMed: 22534978]

73. Conejo R and Lorenzo M, Insulin signaling leading to proliferation, survival, and membrane ruffling in C2C12 myoblasts, Journal of cellular physiology, 2001, 187, 96-108. [PubMed: 11241354]

74. Nicholson DW, Ali A, Thornberry NA, Vaillancourt JP, Ding CK, Gallant M, Gareau Y, Griffin PR, Labelle M, Lazebnik YA and et al., Identification and inhibition of the ICE/CED-3 protease necessary for mammalian apoptosis, Nature, 1995, 376, 37-43. [PubMed: 7596430]

75. Mills JC, Stone NL, Erhardt J and Pittman RN, Apoptotic membrane blebbing is regulated by myosin light chain phosphorylation, The Journal of cell biology, 1998, 140, 627-636. [PubMed: 9456322]

76. Qu G, Yan $\mathrm{H}$ and Strauch AR, Actin isoform utilization during differentiation and remodeling of BC3H1 myogenic cells, Journal of cellular biochemistry, 1997, 67, 514-527. [PubMed: 9383710]

77. Gallo R, Serafini M, Castellani L, Falcone G and Alema S, Distinct effects of Rac1 on differentiation of primary avian myoblasts, Molecular biology of the cell, 1999, 10, 3137-3150. [PubMed: 10512856]

78. Belizario JE, Lorite MJ and Tisdale MJ, Cleavage of caspases-1, $-3,-6,-8$ and -9 substrates by proteases in skeletal muscles from mice undergoing cancer cachexia, British journal of cancer, 2001, 84, 1135-1140. [PubMed: 11308266]

79. Yaoita Y and Nakajima K, Induction of apoptosis and CPP32 expression by thyroid hormone in a myoblastic cell line derived from tadpole tail, J Biol Chem, 1997, 272, 5122-5127. [PubMed: 9030578]

80. Mukasa T, Momoi T and Momoi MY, Activation of caspase-3 apoptotic pathways in skeletal muscle fibers in laminin alpha2-deficient mice, Biochemical and biophysical research communications, 1999, 260, 139-142. [PubMed: 10381357]

81. Fernando P, Kelly JF, Balazsi K, Slack RS and Megeney LA, Caspase 3 activity is required for skeletal muscle differentiation, Proc Natl Acad Sci U S A, 2002, 99, 11025-11030. [PubMed: 12177420]

82. Culotta VC, Yang M and O'Halloran TV, Activation of superoxide dismutases: putting the metal to the pedal, Bba-Bioenergetics, 2006, 1763, 747-758. [PubMed: 16828895]

83. Lustgarten MS, Jang YC, Liu Y, Qi W, Qin Y, Dahia PL, Shi Y, Bhattacharya A, Muller FL, Shimizu T, Shirasawa T, Richardson A and Van Remmen H, MnSOD deficiency results in elevated oxidative stress and decreased mitochondrial function but does not lead to muscle atrophy during aging, Aging cell, 2011, 10, 493-505. [PubMed: 21385310]

84. Kuwahara H, Horie T, Ishikawa S, Tsuda C, Kawakami S, Noda Y, Kaneko T, Tahara S, Tachibana T, Okabe M, Melki J, Takano R, Toda T, Morikawa D, Nojiri H, Kurosawa H, Shirasawa T and Shimizu T, Oxidative stress in skeletal muscle causes severe disturbance of exercise activity without muscle atrophy, Free radical biology \& medicine, 2010, 48, 1252-1262. [PubMed: 20156551]

85. Lee S, Van Remmen $\mathrm{H}$ and Csete $\mathrm{M}$, Sod2 overexpression preserves myoblast mitochondrial mass and function, but not muscle mass with aging, Aging cell, 2009, 8, 296-310. [PubMed: 19627269]

86. Fraústo da Silva JJR and Williams RJP, The biological chemistry of the elements : the inorganic chemistry of life, Oxford University Press, Oxford, 2nd edn., 2001.

87. Linder MC and Hazegh-Azam M, Copper biochemistry and molecular biology, The American journal of clinical nutrition, 1996, 63, 797S-811S.

88. Galvez-Peralta M, He L, Jorge-Nebert LF, Wang B, Miller ML, Eppert BL, Afton S and Nebert DW, ZIP8 zinc transporter: indispensable role for both multiple-organ organogenesis and hematopoiesis in utero, PloS one, 2012, 7, e36055.

89. Wang CY, Jenkitkasemwong S, Duarte S, Sparkman BK, Shawki A, Mackenzie B and Knutson MD, ZIP8 is an iron and zinc transporter whose cell-surface expression is up-regulated by cellular iron loading, J Biol Chem, 2012, 287, 34032-34043. [PubMed: 22898811]

90. Besecker B, Bao S, Bohacova B, Papp A, Sadee W and Knoell DL, The human zinc transporter SLC39A8 (Zip8) is critical in zinc-mediated cytoprotection in lung epithelia, American journal of 
physiology. Lung cellular and molecular physiology, 2008, 294, L1127-1136. [PubMed: 18390834]

91. Mei Z, Yan P, Wang Y, Liu S and He F, Knockdown of zinc transporter ZIP8 expression inhibits neuroblastoma progression and metastasis in vitro, Molecular medicine reports, 2018, 18, 477485. [PubMed: 29749445]

92. Kim JH, Jeon J, Shin M, Won Y, Lee M, Kwak JS, Lee G, Rhee J, Ryu JH, Chun CH and Chun JS, Regulation of the catabolic cascade in osteoarthritis by the zinc-ZIP8-MTF1 axis, Cell, 2014, 156, 730-743. [PubMed: 24529376]

93. Tavera-Montanez C, Hainer SJ, Cangussu D, Gordon SJV, Xiao Y, Reyes-Gutierrez P, Imbalzano AN, Navea JG, Fazzio TG and PADILLA-BENAVIDES T, MTF1, a classic metal sensing transcription factor, promotes myogenesis in response to copper, bioRxiv, 2019, DOI: $10.1101 / 534271,534271$.

94. Machado L, Esteves de Lima J, Fabre O, Proux C, Legendre R, Szegedi A, Varet H, Ingerslev LR, Barres R, Relaix F and Mourikis P, In Situ Fixation Redefines Quiescence and Early Activation of Skeletal Muscle Stem Cells, Cell reports, 2017, 21, 1982-1993. [PubMed: 29141227]

95. Bradford MM, A rapid and sensitive method for the quantitation of microgram quantities of protein utilizing the principle of protein-dye binding, Anal Biochem, 1976, 72, 248-254. [PubMed: 942051]

96. Leary SC, Cobine PA, Kaufman BA, Guercin GH, Mattman A, Palaty J, Lockitch G, Winge DR, Rustin P, Horvath R and Shoubridge EA, The human cytochrome c oxidase assembly factors SCO1 and SCO2 have regulatory roles in the maintenance of cellular copper homeostasis, Cell metabolism, 2007, 5, 9-20. [PubMed: 17189203]

97. Beauchamp C and Fridovich I, Superoxide dismutase: improved assays and an assay applicable to acrylamide gels, Anal Biochem, 1971, 44, 276-287. [PubMed: 4943714] 


\section{Significance to metallomics}

Trace elements are emerging as critical components for mammalian tissue development but are potentially toxic, so their homeostasis must be tightly regulated. Recent studies have reported influxes of copper and zinc during skeletal muscle cell differentiation. This study demonstrates that muscle differentiation is tightly coupled with increased manganese (Mn) and Mn-dependent superoxide dismutase 2 (SOD2). Here, we probe the functional requirements for the Mn, Zn, and Fe transporters ZIP8 and ZIP14, in skeletal muscle cells, and demonstrate that ZIP8 is essential in this cell type while ZIP14 is dispensable. This study is the first to report on the functional relevance of two members of the ZIP family of transporters in the skeletal muscle lineage. 

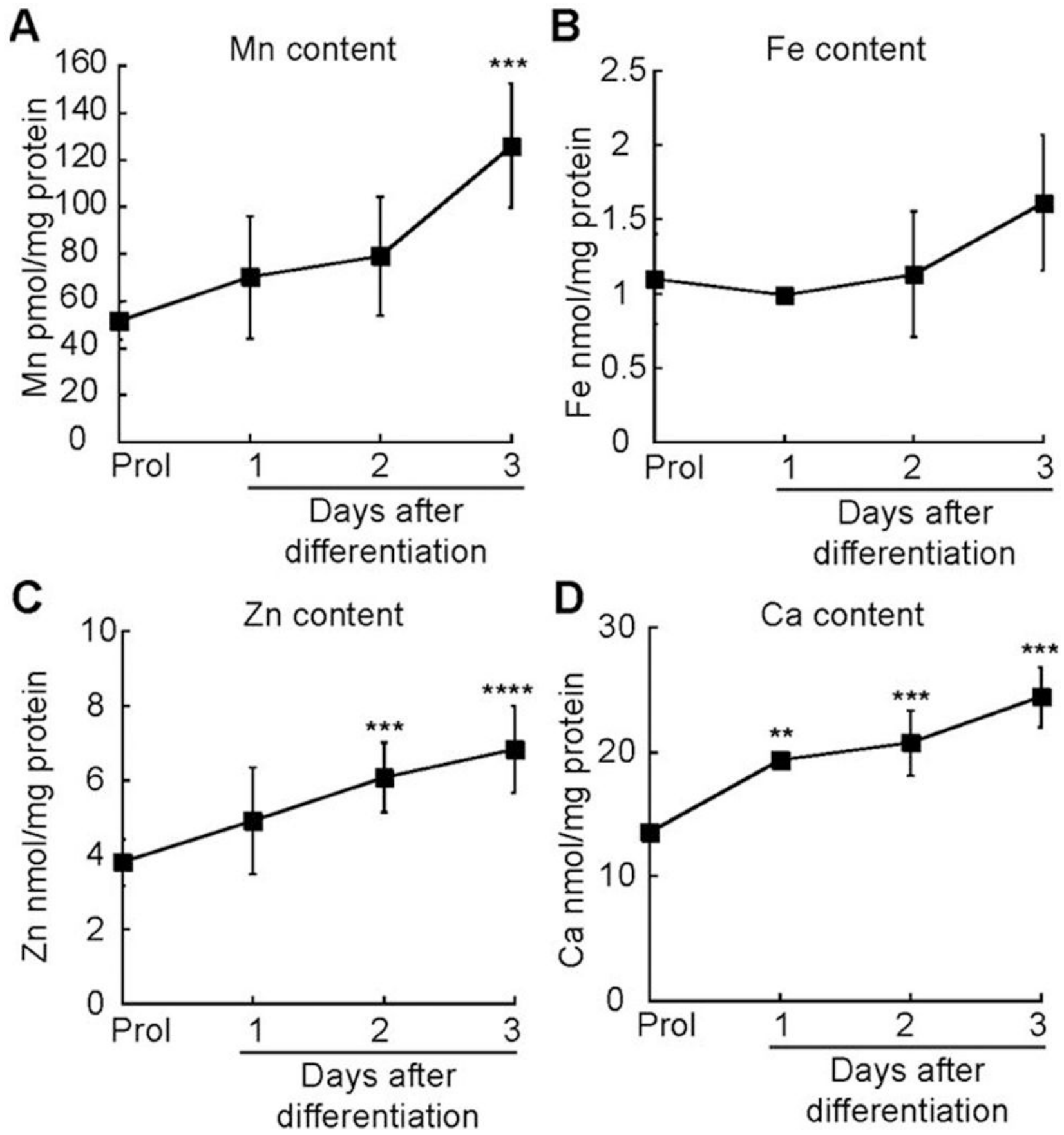

Figure 1. Metal intake in differentiating primary myoblasts.

Whole cell metal content analyses of proliferating and differentiating wild type myoblasts. (A) Manganese. (B) Iron. (C) Zinc. (D) Calcium. All data were obtained using ICP-OES and normalized to total protein. Statistical analyses showed significant differences in metal accumulation in differentiating myoblasts compared to proliferating cells. Data is the mean $\pm \mathrm{SE}$ for three independent biological replicates. $* * * * \mathrm{P}<0.001, * * * \mathrm{P}^{<} 0.005, * * \mathrm{P}^{<} 0.01$ 


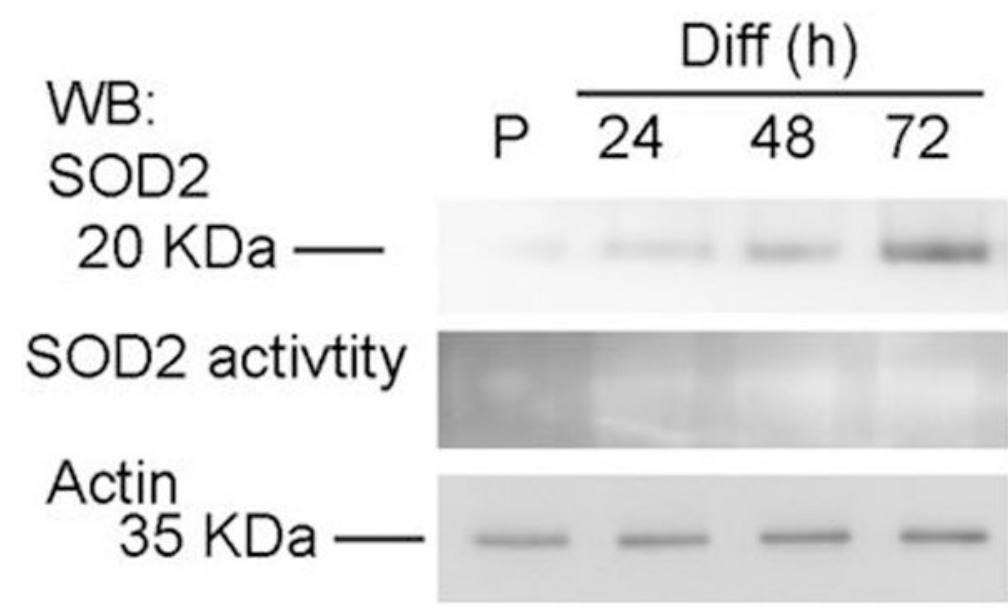

Figure 2. SOD2 expression and activity increases as a consequence of myogenic differentiation. Representative immunoblots and activity gels analyses for SOD2 in proliferating and differentiating myoblasts expressing, Actin and Coomasie-stained membranes were used as loading controls (Supp. Fig. 8). 
A

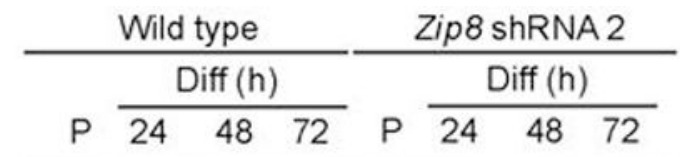

ZIP8

$55 \mathrm{KDa}-$

Actin $35 \mathrm{KDa}$
B

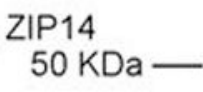

Actin $35 \mathrm{KDa}-$
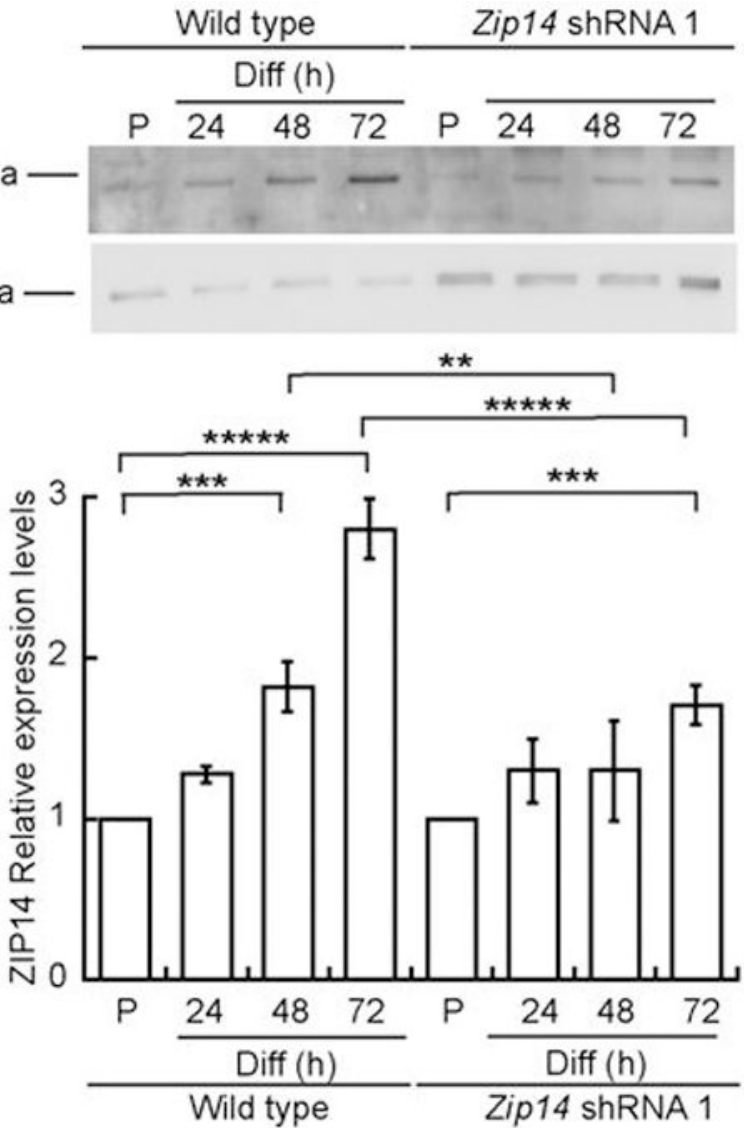

Figure 3. ZIP8 and ZIP14 expression in proliferating and differentiating wild type and shRNA knockdown primary myoblasts derived from mouse satellite cells.

(A) Representative immunoblot (top) and quantification (bottom) of ZIP8 levels in proliferating myoblasts and differentiated cells for 24,48 , and $72 \mathrm{~h}$ in wild type (left) and Zip8 shRNA expressing cells (right). (B) Representative immunoblot of ZIP14 levels in proliferating and differentiating wild type (left) and Zip14 shRNA myoblasts (right). For all samples, shown is the mean $\pm \mathrm{SE}$ of three independent biological replicates. Immunoblots against actin or Coomasie-stained membranes (Supp. Fig. 8) were used as loading controls. Samples were compared to the corresponding wild type or mutant proliferation time point, and the; mutants were compared also to the equivalent time point in wild type cells.

$* * * * * \mathrm{P}<0.0001 * * * * \mathrm{P}<0.001, * * * \mathrm{P}^{<} 0.005, * * \mathrm{P}^{<} 0.01$ 
A

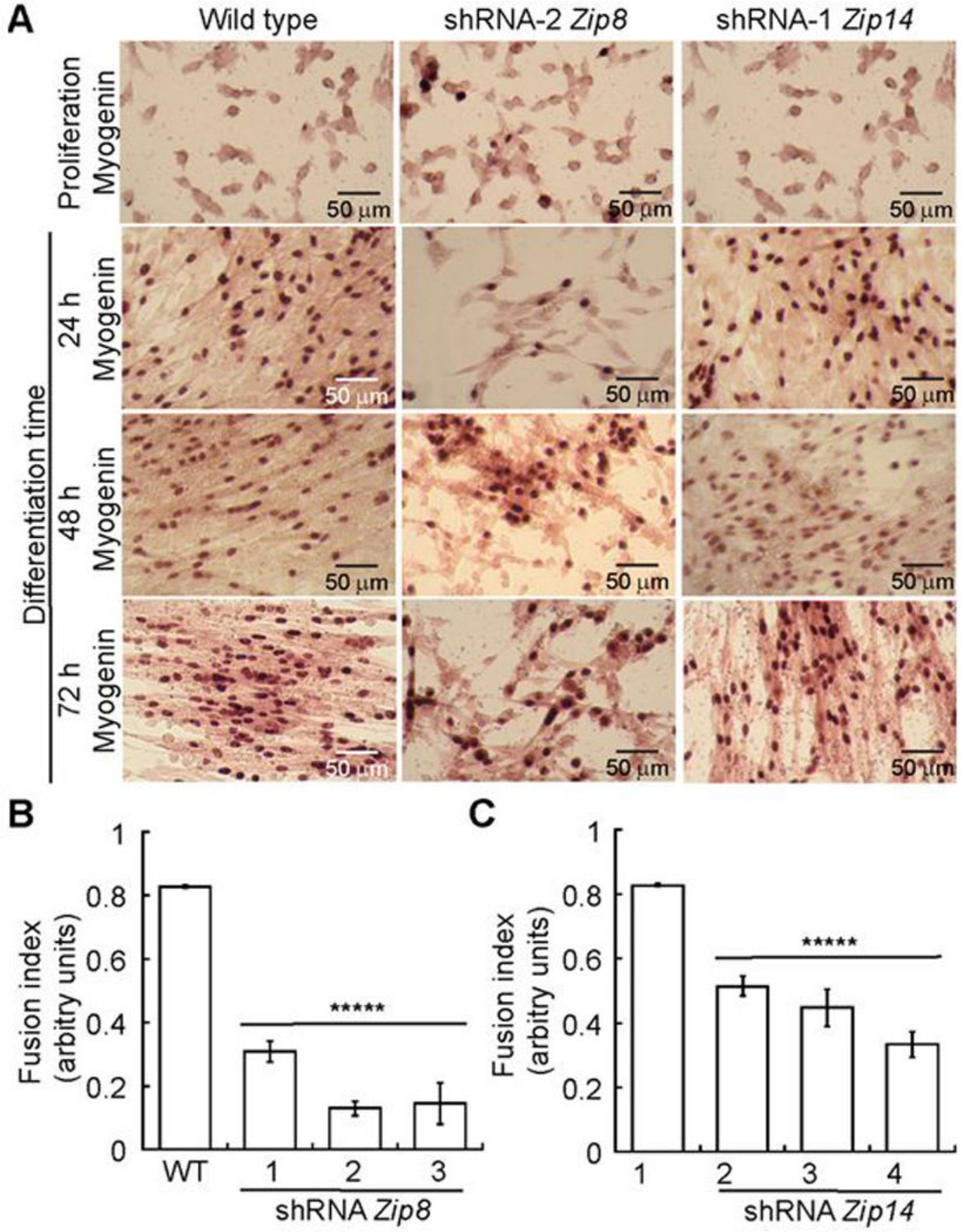

shRNA-1 Zip14

Figure 4. Knockdown of Zip8 impairs differentiation of primary myoblasts.

(A) Representative light micrographs of wild type, Zip8 and Zip14 knockdown myoblasts grown in proliferating conditions or at 24,48 and $72 \mathrm{~h}$ after inducing differentiation. Cells were immunostained with an anti-Myogenin antibody. Calculated fusion index for Zip8- (B) and Zip14-shRNA treated myoblasts. (C) Data represent mean \pm SE for three independent experiments. $* * * * * \mathrm{P}<0.0001$ 
A

WT

-scr shRNA

- Zip8 ShRNA 2
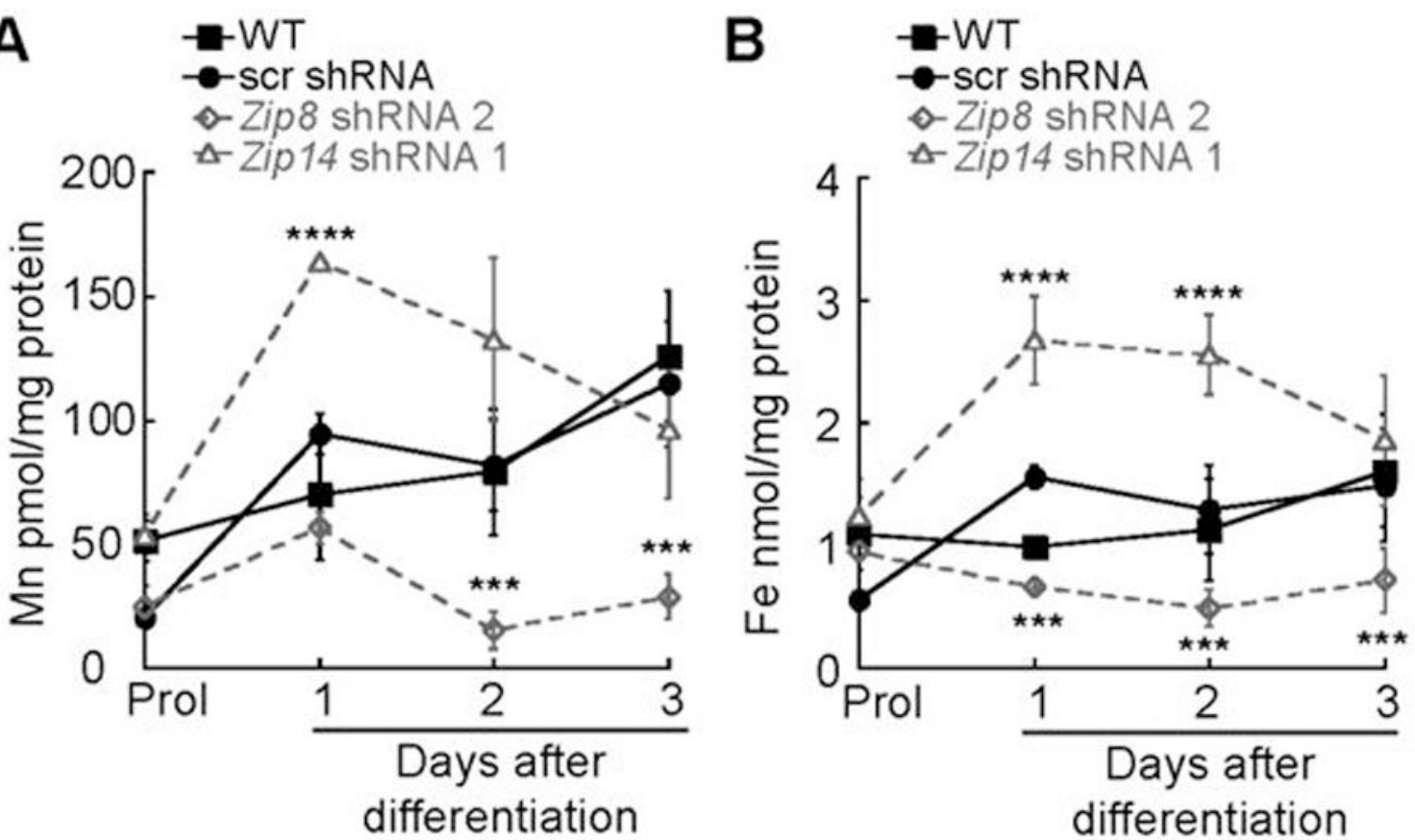

C
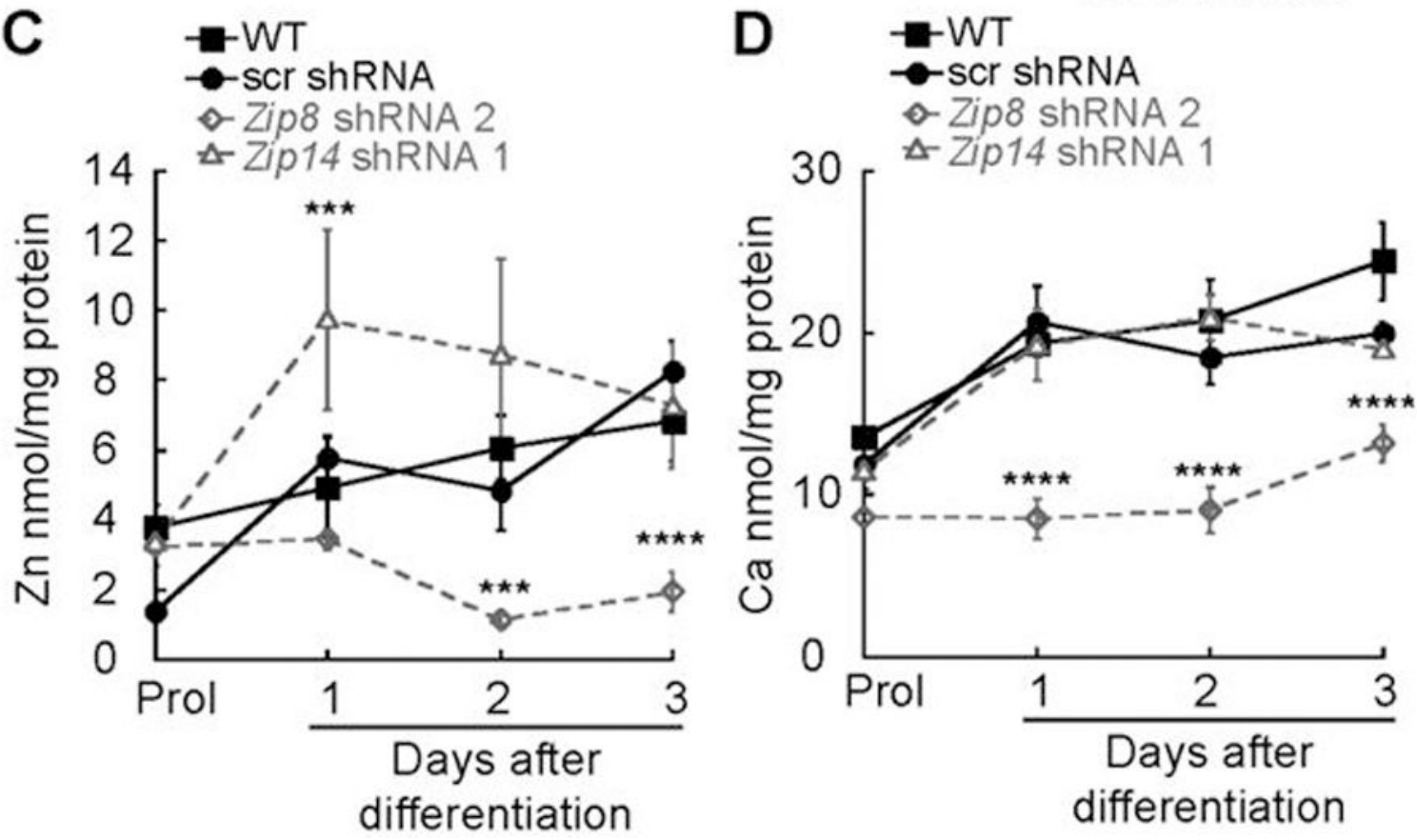

Figure 5. Knockdown of Zip8, but not Zip14 impairs metal intake in differentiating primary myoblasts.

Whole cell metal content analyses of proliferating and differentiating wild type or myoblasts transduced with scrambled (scr), Zip8 or Zip14 shRNA. Statistical analyses showed significant differences in metal accumulation in differentiating myoblast comparing to the corresponding time point of wild type cells. (A) Manganese. (B) Iron. (C) Zinc. (D) Calcium. All data were obtained using ICP-OES and normalized to total protein. Shown is mean \pm SE for three independent biological replicates. $* * * * \mathrm{P}<0.001, * * * \mathrm{P}^{<} 0.005$. 

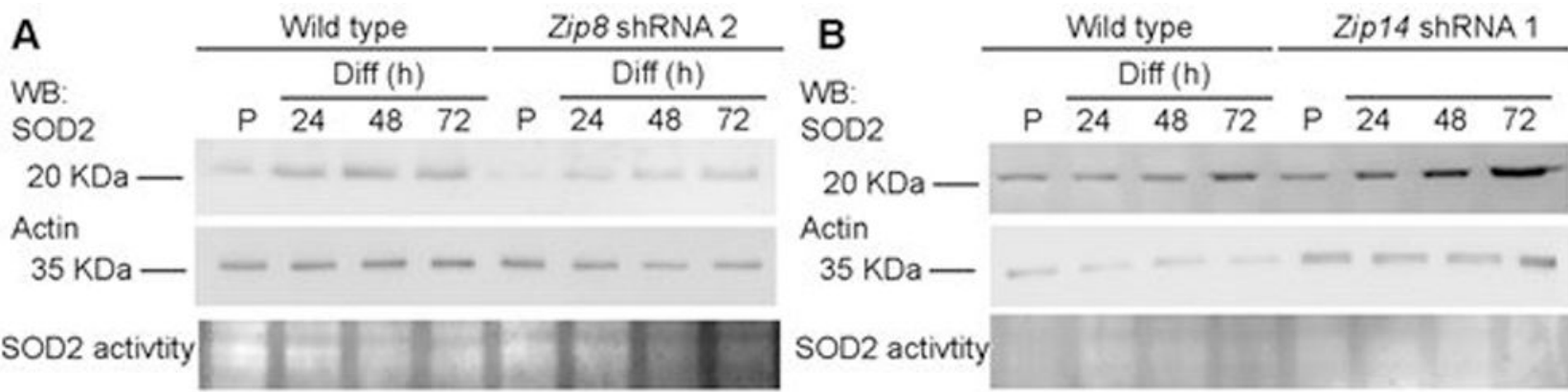
$20 \mathrm{KDa}-$

Actin $35 \mathrm{KDa}-$ SOD2 activtity
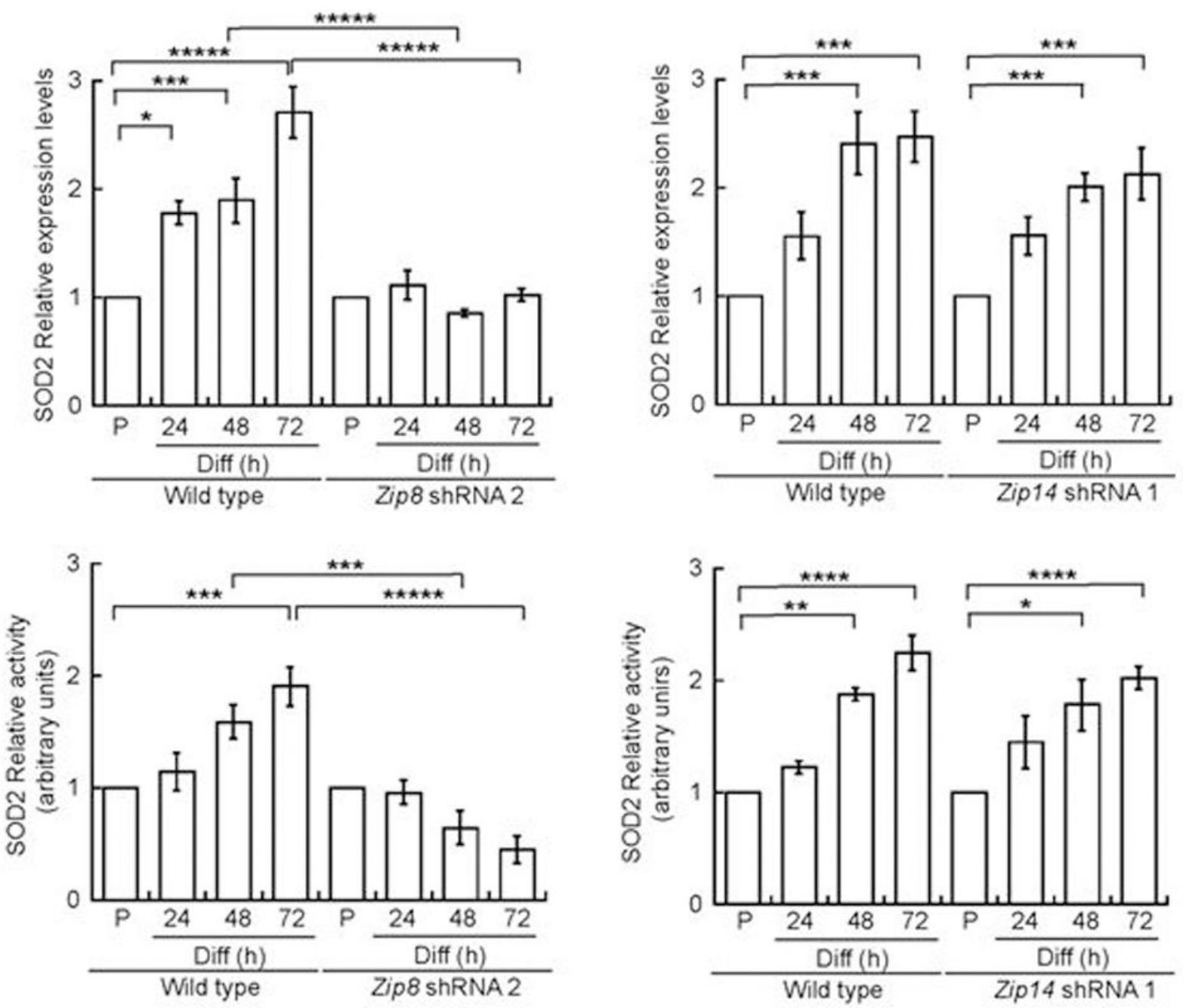

Figure 6. SOD2 expression and activity is decreased in Zip8, but not Zip14 knockdown primary myoblasts.

Representative Western blots, activity gels (top panels) and quantification of SOD2 levels and activity (bottom panels) in wild type and Zip8 shRNA cell (A), and Zip14 shRNA cells. For all samples, blots against actin and Coomassie-stained membranes were used as loading controls (Supp. Fig. 8). Shown is mean \pm SE for three biological replicates. For wild type differentiating myoblasts, statistical analyses showed significant differences when compared to proliferating cells. Bonferroni statistical analyses for Zip8-knock down cells showed significant differences when compared to control cells at the corresponding time points, and 
also when compared to the mutant's proliferation point. Similar to control cells, Zip14 knockdown cells showed significant differences when compared to proliferating Zip14 mutant myoblasts; *****P $<0.0001 * * * * \mathrm{P}<0.001, * * * \mathrm{P}^{<} 0.005, * * \mathrm{P}^{<} \quad 0.01, * \mathrm{P} \leq 0.05$ 


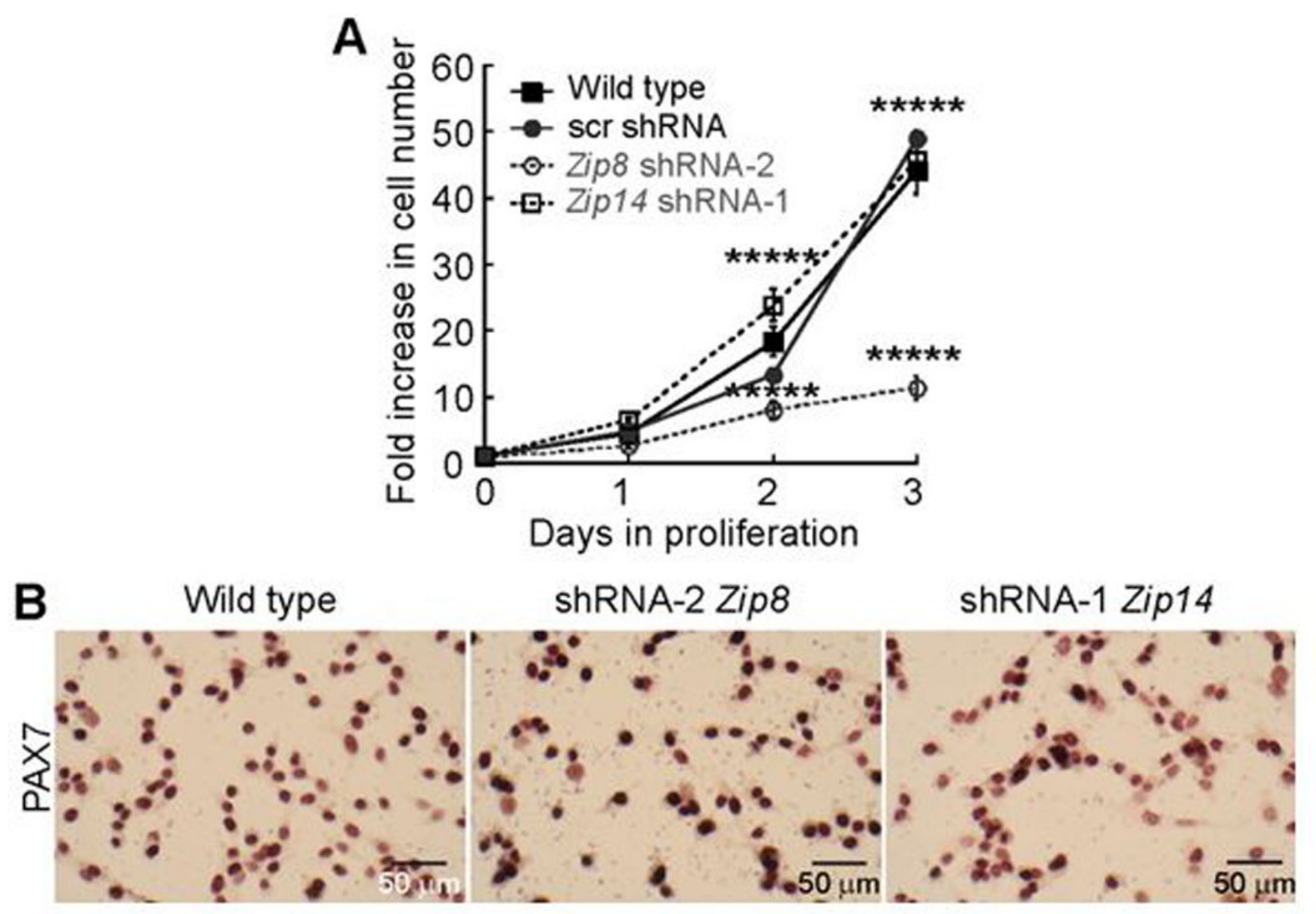

Figure 7. Partial depletion of Zip8, but not Zip14, impairs growth of primary myoblasts. Cell counting assay of proliferating wild type myoblasts, myoblasts transduced with scrambled shRNA (shRNA scr, B,C), Zip8(A) or Zip14 shRNAs (B). Data in A-C are mean $\pm \mathrm{SE}$ for three independent experiments. $* * * * * \mathrm{P}<0.0001$ relative to $0 \mathrm{~h}$ of proliferation. (C) Representative light micrographs of proliferating wild type myoblasts, Zip8 or Zip14 knockdown myoblasts immunostained for Pax 7. 

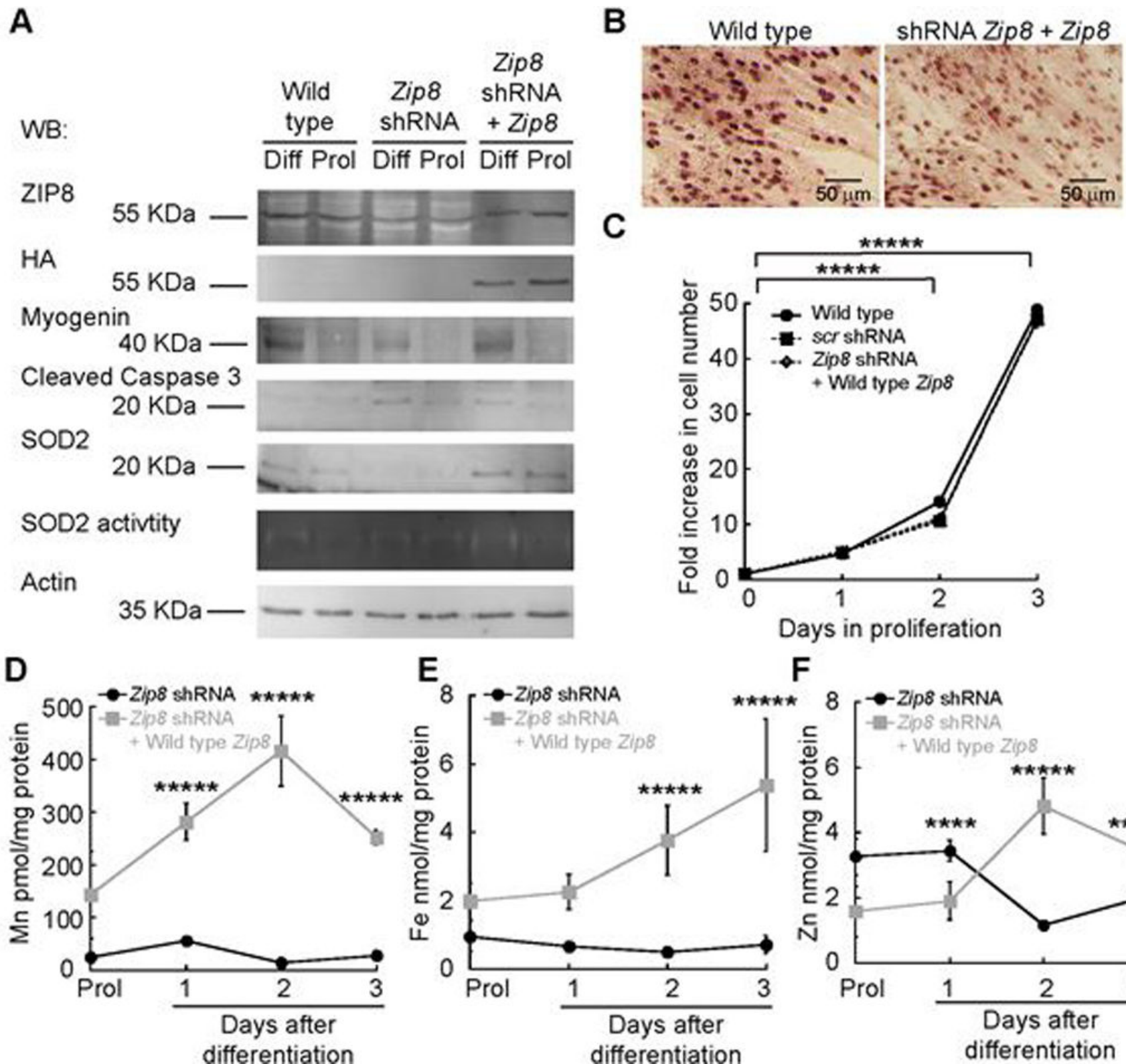

C

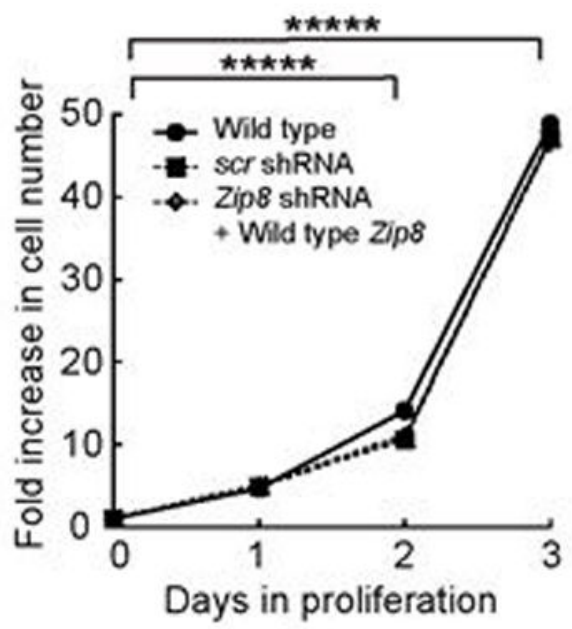

E

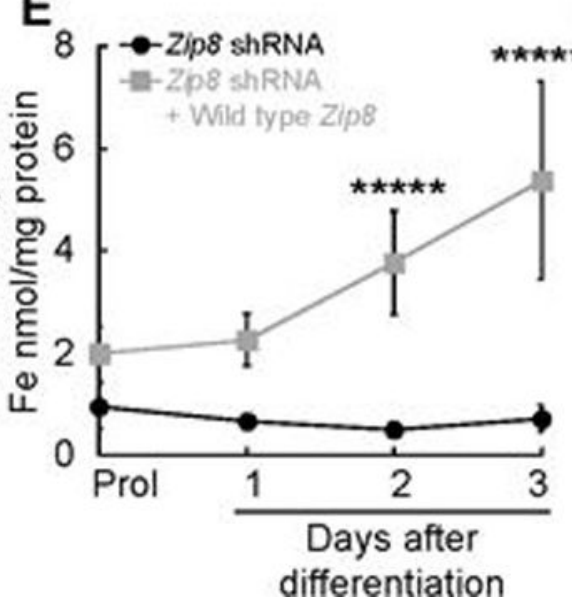

$\mathbf{F}$

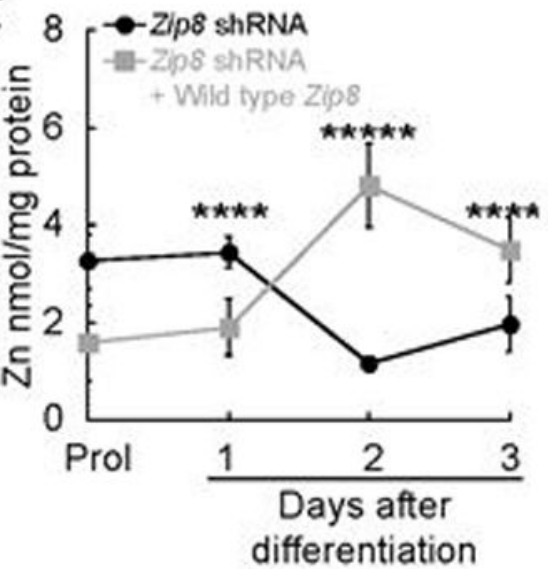

Figure 8. exogenous ZIP8 rescued the proliferation and differentiation phenotype of Zip8 knockdown myoblasts.

(A) Representative Western blot of myoblasts transduced with the murine wild type Zip8.

Detection of ZIP8, an anti-HA antibody was used to detect the tag associated to the exogenous protein. Myogenin, Caspase 3 and SOD2 antibodies were used. Actin is the loading control. SOD2 activity was also evaluated in gel. (B) Representative light micrographs of differentiating wild type myoblasts and those transduced with an shRNA against Zip8 (shRNA-2) complemented with the murine wild type Zip8 at $48 \mathrm{~h}$ post differentiation. Cells were immunostained with an anti-Myogenin antibody. (C) Cell counting assay of proliferating wild type myoblasts, cells transduced with scrambled shRNA (scr shRNA), and cells complemented with Zip8. Data is the mean \pm SE for three 
independent experiments. ICP analysis of (D) Mn, (E) Fe, (F) Zn in cells Zip8 shRNA cells complemented with wild type Zip8. 


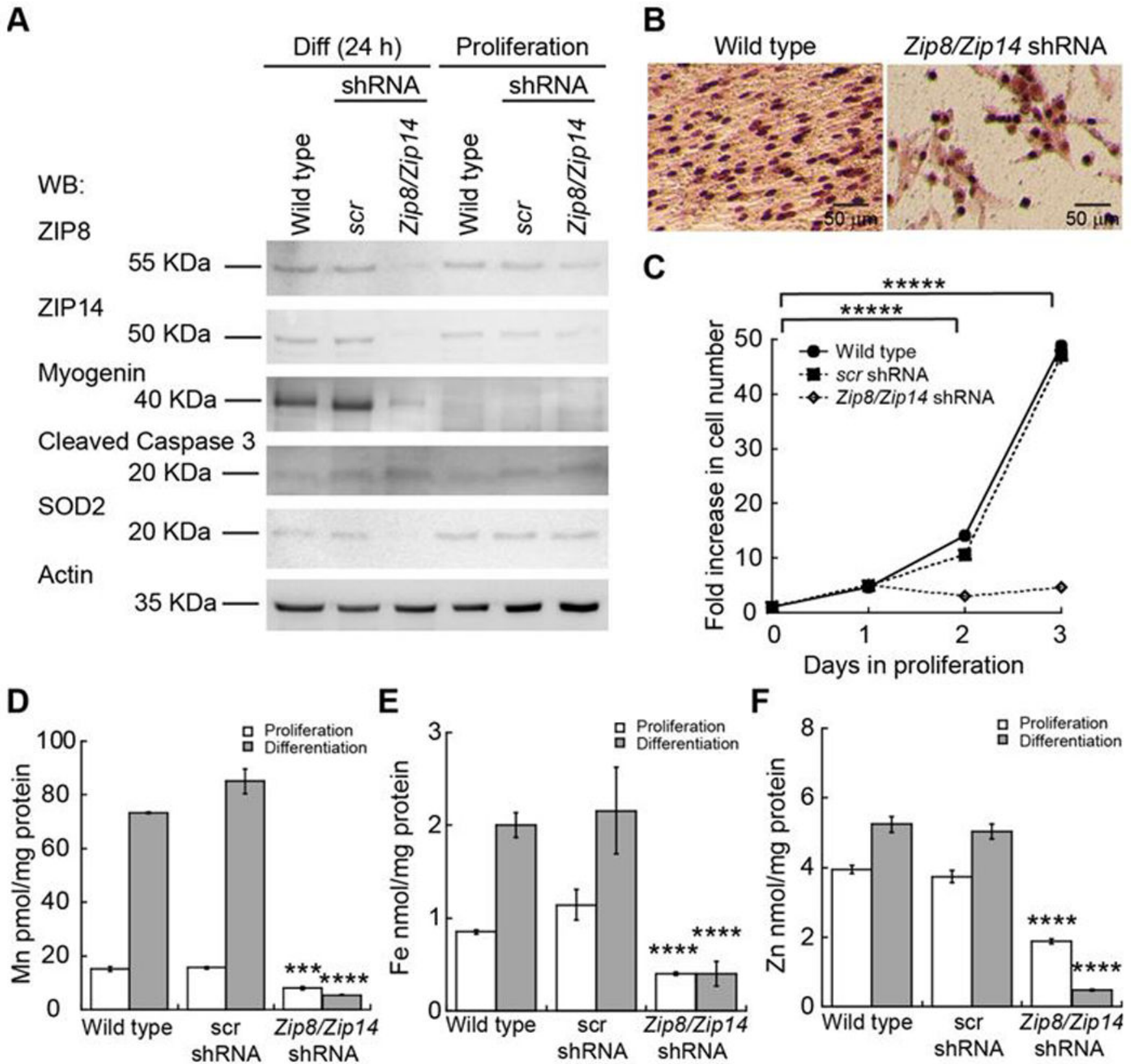

Figure 9. Zip8 and Zip14 double knockdown myoblasts present severe proliferation and differentiation defects.

(A) Representative Western blot of myoblasts transduced with the murine wild type Zip8 and Zip14. The antibodies used were ZIP8, ZIP14, Myogenin, Caspase 3 and SOD2 antibodies were used. Actin is the loading control. SOD2 activity was also evaluated in gel.

(B) Representative light micrographs of differentiating wild type myoblasts and those transduced with scramble and with both shRNA against Zip8 and Zip14 at 24 h post differentiation. Cells were immunostained with an anti-Myogenin antibody. (C) Cell counting assay of proliferating wild type myoblasts, scrambled shRNA and double mutant. Data is the mean $\pm \mathrm{SE}$ for three independent experiments. Whole cell metal content analyses of proliferating and differentiating wild type or myoblasts transduced with scrambled (scr), 
Zip8 and Zip14 shRNA. Statistical analyses showed significant differences in metal accumulation in differentiating myoblasts (D) Manganese. (E) Iron. (F) Zinc. Data was obtained using ICP-OES and normalized to total protein. Shown is mean \pm SE for three independent biological replicates. $* * * * \mathrm{P}<0.001, * * * \mathrm{P}^{<} 0.005$ 
A
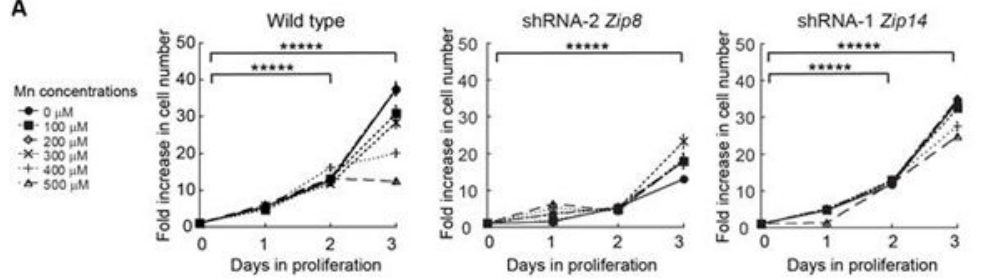

Dild type

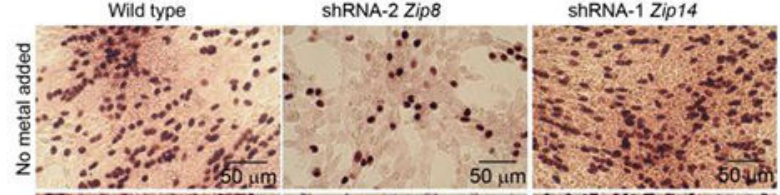

B

Wild type
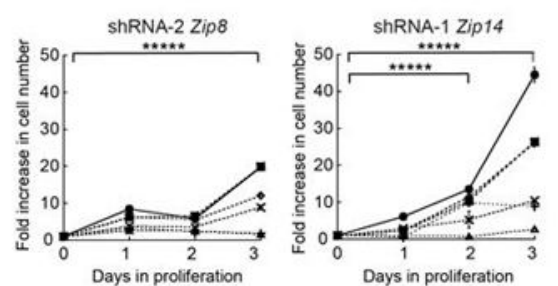

C

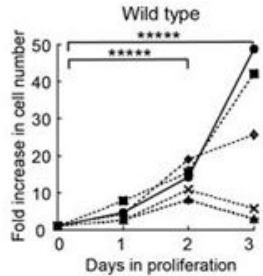

Days in protiferaty
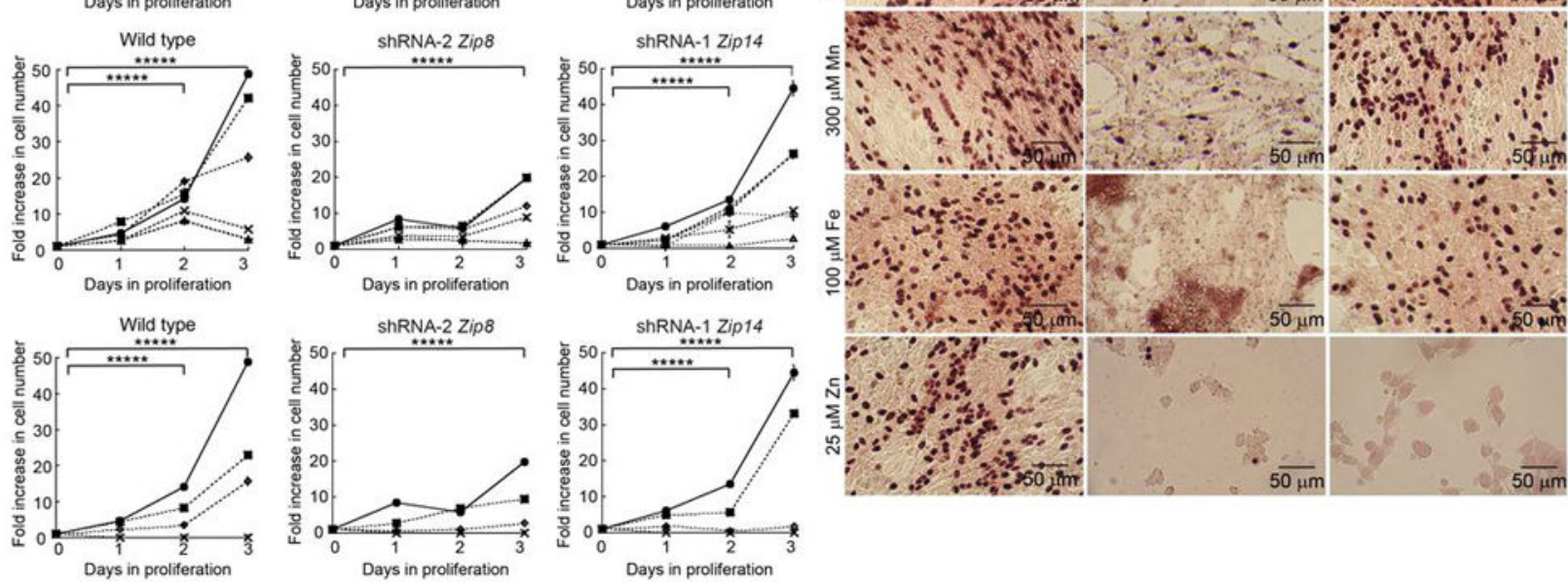

Figure 10. Manganese supplementation partially rescues the proliferation defect, but not the differentiation phenotype of Zip8 knockdown myoblasts.

Cell counting assays performed in myoblasts expressing Zip8 and Zip14 shRNAs grown in medium supplemented with exogenous $\mathrm{Mn}(\mathbf{A})$, Fe (B) or $\mathrm{Zn}(\mathbf{C})$. Statistical analyses showed significant differences when comparing differentiating myoblasts to proliferating cells. For all experiments, data represent mean \pm standard error for three biological replicates. $* * * * * \mathrm{P}<0.0001$. (D) Representative light micrographs of differentiating wild type myoblasts and those transduced with scramble and shRNA against Zip8 or Zip14 at $48 \mathrm{~h}$ post differentiation. Cells were immunostained with an anti-Myogenin antibody. 


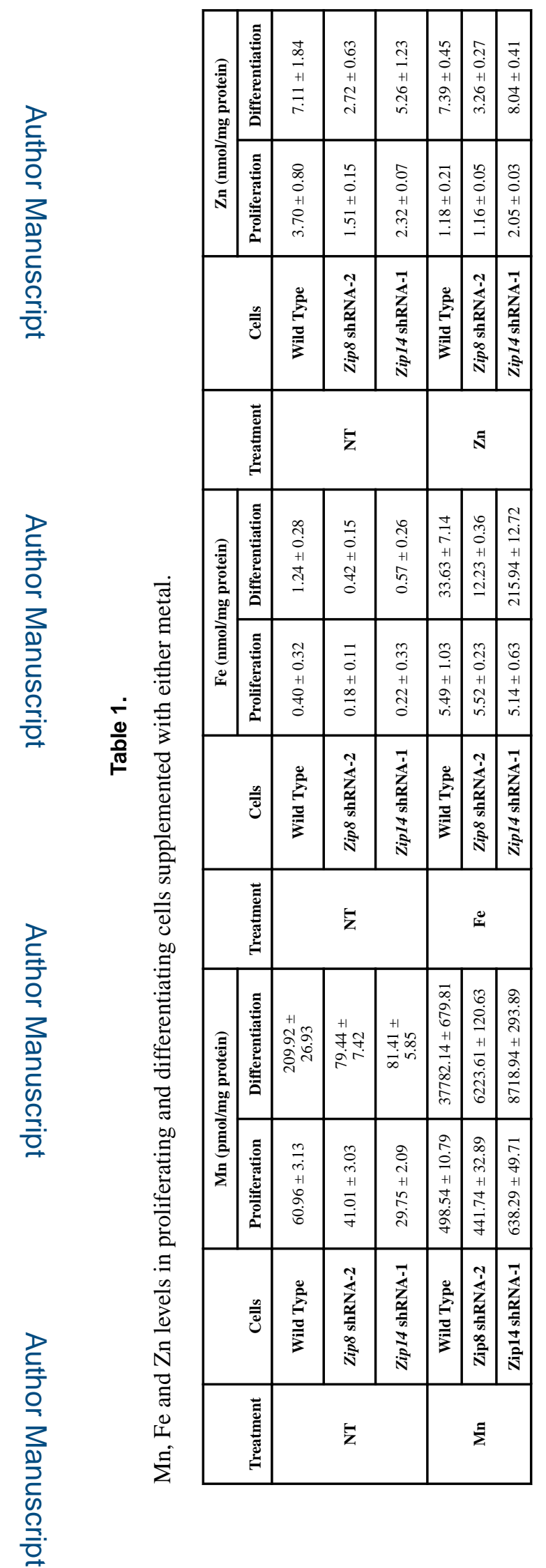

Metallomics. Author manuscript; available in PMC 2020 June 19. 